\title{
Biogeochemistry of dissolved inorganic nutrients in an oligotrophic coastal mariculture region of the northern Shandong Peninsula, north Yellow Sea
}

\author{
Bo Yang ${ }^{\mathrm{a}, \mathrm{b}}$, Xuelu Gao ${ }^{\mathrm{a}, \mathrm{b}, *}$, Jianmin Zhao ${ }^{\mathrm{a}}$, Yuxi Lu ${ }^{\mathrm{a}, \mathrm{b}}$, Tianci Gao ${ }^{\mathrm{a}, \mathrm{b}}$ \\ ${ }^{a}$ CAS Key Laboratory of Coastal Zone Environmental Processes and Ecological Remediation, Yantai Institute of Coastal Zone Research, Chinese Academy of Sciences, \\ Yantai, Shandong, 264003, China \\ ${ }^{\mathrm{b}}$ University of Chinese Academy of Sciences, Beijing, 100049, China
}

\section{A R T I C L E I N F O}

\section{Keywords:}

Biogeochemical processes

Seasonal variations

Coastal waters

Eutrophication assessment

Nutrient budget

\begin{abstract}
A B S T R A C T
Fourteen field cruises were carried out in a mariculture region of the northern Shandong Peninsula, North Yellow Sea, China from 2016 to 2017 for a better understanding of the biogeochemical behaviors, sources and export of dissolved inorganic nutrients. The spatial variations of nutrients were not obvious due to the influence of complex hydrological and biochemical conditions. Potential nutritional level was characterized in oligotrophy, and trophic status was rated at medium level. A preliminary estimation of nutrient budgets demonstrated that the dissolved inorganic nitrogen (DIN) load was mainly from atmospheric deposition and scallop excretion, accounting for $56.9 \%$ and $35.6 \%$ of its total influx. Scallop excretion and sediment release were the major source of phosphate (DIP), contributing to $25.2 \%$ and $44.3 \%$, while dissolved silicon (DSi) was mainly from sediment release, accounting for $94.2 \%$. In addition, about $136.7 \times 10^{3}, 7.3 \times 10^{3}$ and $485.5 \times 10^{3} \mathrm{~mol} \mathrm{~km}^{-2} \mathrm{yr}^{-1}$ of $^{2}$ DIN, DIP and DSi could be converted into other forms, e.g. organic and particulate matter and gas species.
\end{abstract}

\section{Introduction}

Dissolved inorganic nitrogen (DIN), phosphorus (DIP) and silicon (DSi), the key indicators in evaluating the "health status" of ecological environment, play an essential role in the biological productivities, ecosystem functions and biogeochemical processes in marine environments (Zhang et al., 2007; Liu et al., 2009, 2012; Lui and Chen, 2011, 2012; Asanuma et al., 2014; Li et al., 2014; Yang et al., 2018). For example, nutrient enrichment can stimulate primary productivity (Borum and Sand Jensen, 1996), sometimes leading to exceptional algal blooms, which can result in hypoxia in bottom waters as stratification develops (Anderson and Taylor, 2001; Rabotyagov et al., 2010; Li et al., 2016). In addition, alterations in nutrient ratios and quantities can induce changes in the composition of phytoplankton species and foodweb structure (Grosse et al., 2017; Lehtinen et al., 2017; Barbiero et al., 2018). In the last few decades, studies on source, distribution and rate of utilization of these inorganic nutrient components have become an urgent research topic in various aquatic ecosystems.

Coastal waters account for only a small portion of the ocean surface area, $\sim 7-8 \%$, but provide $\sim 25 \%$ of the global ocean primary production (Smith and Hollibaugh, 1993). In these ecosystems, distribution and behavior of nutrients exhibit considerable variations depending upon their external supply and removal. Generally, the main sources of nutrients to coastal waters are river input, regeneration of organic matter, atmospheric deposition, submarine groundwater discharge and onshore transport from the open sea (Liu et al., 2005, 2009, 2012). Phytoplankton uptake is the main pathway for the removal of excess nutrients. In addition, human activities such as agriculture, aquaculture, sewage treatment and burning of fossil fuels also significantly affect the distribution of nutrients (Liu et al., 2012). In recent decades, due to rapid urbanization and growth of aquaculture in coastal areas, the concentration and structure of nutrients in coastal waters have changed significantly, resulting in a number of environmental problems, e.g. hypoxia, seawater acidification, harmful or toxic algal blooms and shifts in species composition of plankton, posing a serious threat to the marine ecosystem (Zhang et al., 2007; Bricker et al., 2008; Heisler et al., 2008; Glibert et al., 2010; Qu and Kroeze, 2010; Li et al., 2014). It is thus important to explore the biogeochemical cycle of nutrients and its main controlling factors, which has important scientific and practical significance for regional material cycling and environmental evolution and protection.

The North Yellow Sea (NYS), as a semi-closed marginal sea and one of the world's most representative shallow continental shelves (Yang et al., 2010), is rich in natural resources and plays an important role in

\footnotetext{
* Corresponding author. CAS Key Laboratory of Coastal Zone Environmental Processes and Ecological Remediation, Yantai Institute of Coastal Zone Research, Chinese Academy of Sciences, Yantai, Shandong, 264003, China.

E-mail address: xlgao@yic.ac.cn (X. Gao).
} 
human life and social development in the eastern littoral of China. The north coast of the Shandong Peninsula, one of the fastest developing areas in China, is located next to the NYS, with a history of over 60 years of marine raft culture (mainly scallops) in the coastal waters. Over the last two decades, a number of environmental problems have emerged due to ever-increasing pressures from human activities in this region. Through the field investigation in the coastal waters of the northern Shandong Peninsula from 2015 to 2017, it was found that there was a hypoxia zone existent in the bottom water in summer, and aerobic decomposition of marine autogenous organic matter could be the main biochemical reason for the formation of hypoxia (Yang et al., 2018; Yang and Gao, 2019). In addition, phytoplankton reproduction could be the most important factor affecting the biogeochemical cycle of organic matter (Yang et al., 2018; Zhang et al., 2018; Yang and Gao, 2019). However, as a key factor affecting phytoplankton reproduction, the biogeochemical cycle of nutrients in this area has not yet been studied. Therefore, this study, which was based on the data of 14 field cruises, investigated the dissolved inorganic nutrients to examine their composition and spatiotemporal variations and reveal the key processes that control their dynamics in this coastal area.

\section{Materials and methods}

\subsection{Study area}

The research area, one of the intensively maricultured areas in China with a mean depth of approximately $15 \mathrm{~m}$, is located in the coastal waters around the Yangma Island along the Yantai-Weihai shoreline in the northern Shandong Peninsula (Fig. 1). Several small seasonal rivers, e.g. Xin'an River, Yuniao River, Qinshui River and Yangting River are running along the coastline. The area is dominated by regular semi-diurnal tides; currents flow from the east to the west at flood tides and reverse at ebb tides (Jia et al., 2007), and climatic variations are primarily dominated by the East Asian Monsoon (Chen, 2009). Meteorological conditions exhibit a pronounced seasonal cycle, which determines strong variations in seawater temperature, salinity and water column stratification during the year. The annual thermal stratification occurs and lasts from spring to late summer as the temperature rises; in autumn, the water column is mostly homogeneous due to the weather turning cold, which is beneficial to vertical mixing (Yang et al., 2018; Yang and Gao, 2019).

\subsection{Sampling and analyses}

From March 2016 through November 2017, 14 field surveys were conducted in spring (March and May), summer (June, July and August) and autumn (September and November). As shown in Fig. 1, a total of 37 sampling sites were covered in seven transects. Discrete water samples were collected with a Niskin sampler. Two layers of water samples were obtained at each sampling site, i.e. surface water $(1 \mathrm{~m}$ under the sea surface) and bottom water ( $1 \mathrm{~m}$ above the seabed). After collection, about $100 \mathrm{ml}$ of each sample were filtered through pre-acidcleaned and pre-combusted $\left(500{ }^{\circ} \mathrm{C}\right.$ for $\left.5 \mathrm{~h}\right) 0.7 \mu \mathrm{m}$ pore size Whatman $\mathrm{GF} / \mathrm{F}$ filters. The filtrates were gathered in $50 \mathrm{ml}$ acid-cleaned polyethylene bottles and stored at $-20^{\circ} \mathrm{C}$ until further analysis.

The concentrations of DIN, DIP and DSi were obtained by measuring nitrate $\left(\mathrm{NO}_{3}{ }^{-}\right)$, nitrite $\left(\mathrm{NO}_{2}{ }^{-}\right)$, ammonium $\left(\mathrm{NH}_{4}{ }^{+}\right)$, phosphate $\left(\mathrm{PO}_{4}{ }^{3-}\right)$ and silicate $\left(\mathrm{SiO}_{3}{ }^{2-}\right)$ in the water samples with a SEAL Analytical continuous-flow AutoAnalyzer using the standard colorimetric methods according to Aydin-Onen et al. (2012). The detection limit was $0.02 \mu \mathrm{moll}^{-1}$ for $\mathrm{NO}_{3}{ }^{-}, \mathrm{NO}_{2}{ }^{-}$and $\mathrm{SiO}_{3}{ }^{2-}$, and $0.03 \mu \mathrm{moll}^{-1}$ for $\mathrm{NH}_{4}{ }^{+}$, and $0.01 \mu \mathrm{moll} 1^{-1}$ for $\mathrm{PO}_{4}{ }^{3-}$. The relative standard deviations (RSD) of repeated determinations of selected samples were less than $5 \%$. DIN concentration was the sum of $\mathrm{NO}_{3}{ }^{-}$, $\mathrm{NO}_{2}{ }^{-}$and $\mathrm{NH}_{4}{ }^{+}$concentrations.

Hydrographic data, including water temperature, salinity, dissolved oxygen (DO) and chlorophyll $a(\mathrm{Chl} a$ ) were measured using a CTD (Seabird) and a YSI sensors, with the precision of $\pm 0.05^{\circ} \mathrm{C}$ (temperature), \pm 0.01 (salinity), $\pm 0.01 \mathrm{mgl}^{-1}$ (DO) and $\pm 0.01 \mu \mathrm{g} 1^{-1}$ (Chl $a$ ).

\subsection{Nutritional status assessment}

\subsubsection{Potential eutrophication}

Phytoplankton absorbs nutrients in seawater according to the Redfield ratio (Redfield, 1963), and there must be some relative excess of nitrogen or phosphorus, which could not be used. Excess nitrogen and phosphorus do not have substantial contribution to eutrophication and could be considered as a potential factor, known as potential eutrophication (Sun et al., 2006). In order to highlight the limiting characteristics of nutrients, DIN and DIP were selected as the evaluation parameters, and the potential eutrophication evaluation model proposed by Guo et al. (1998) was adopted for the evaluation of the nutrient condition in the study area (Table 1).

\subsubsection{Trophic index}

Trophic index (TRIX) was proposed by Vollenweider et al. (1998) and it integrates the most common indicators used for the assessment of eutrophication. The TRIX method has been used for the evaluation of the trophic status of water bodies at the regional level, which varied from oligotrophic to eutrophic condition, such as in the Black, Aegean, Adriatic and Caspian Seas, the coastline of Pesaro and the southeast coast of Mexico (Pettine et al., 2007; Shahrban and Etemadshahidi, 2010; Devlin et al., 2011; Primpas et al., 2011). The index was calculated based on the following formula (Vollenweider et al., 1998; Giovanardi and Vollenweider, 2004; Primpas and Karydis, 2011):

TRIX $=\left[\log _{10}\left(\mathrm{DIN} \times \mathrm{DIP} \times \mathrm{Chl} a \times \mathrm{D} \% \mathrm{O}_{2}\right)+1.5\right] / 1.2$

where DIN, DIP and Chl $a$ represent their corresponding concentrations in $\mu \mathrm{g} \mathrm{l}^{-1} ; \mathrm{D} \% \mathrm{O}_{2}$ represents the absolute value of $\%$ deviation of DO concentration from saturation condition; the numbers 1.5 and 1.2 are scale coefficients proposed by Giovanardi and Vollenweider (2004) to fix the lower limit value of the index and keep the scale in the range of 0-10 (Table 2).

\subsection{Nutrient budget calculation}

Dissolved nutrient budgets for the study system were constructed based on the Land-Ocean Interactions in the Coastal Zone (LOICZ) box model (Gordon et al., 1996). This model has been widely used in the construction of nutrient budgets defining the internal biogeochemical processes and external nutrient inputs of estuarine and coastal ecosystems (Savchuk, 2005; Liu et al., 2009). In order to apply the model, the study system was assumed to be in a steady state and treated as a single well-mixed box. Terrestrial surface input, atmospheric deposition, and the exchange with the Bohai Sea (BS) and the South Yellow Sea (SYS) were included in the model. The mass balance of water and dissolved nutrients in the study area was as follows:

$\mathrm{Q}_{\mathrm{T}}+\mathrm{Q}_{\mathrm{A}}-\mathrm{Q}_{\mathrm{E}}+\mathrm{Q}_{\text {in }}-\mathrm{Q}_{\text {out }}+\triangle \mathrm{Q}=0$

$\mathrm{Q}_{\mathrm{T}} \times \mathrm{C}_{\mathrm{T}}$ (i) $+\mathrm{Q}_{\mathrm{A}} \times \mathrm{C}_{\mathrm{A}}$ (i) $+\mathrm{Q}_{\text {in }} \times \mathrm{C}_{\text {in }}$ (i) $-\mathrm{Q}_{\text {out }} \times \mathrm{C}_{\text {out }}$ (i) $+\triangle \mathrm{M}$ (i) $=0$

where $Q$ represents the water mass of inputs $(+)$ and outflows $(-)$ in the study area; $\triangle Q$ and $\triangle M$ are net budgets of water and dissolved nutrients; $\mathrm{C}$ is the dissolved nutrient concentration in each water column; Subscripts T, A, E, in and out represent terrestrial surface input, atmospheric deposition (including precipitation and dry deposition), evaporation, input from the BS and the SYS to the study area, and output from the study area to the BS and the SYS; (i) represents a certain nutrient of DIN, DIP and DSi.

For terrestrial surface input, it mainly comes from four small seasonal rivers, e.g. the Xin'an River, the Yuniao River, the Qinshui River 


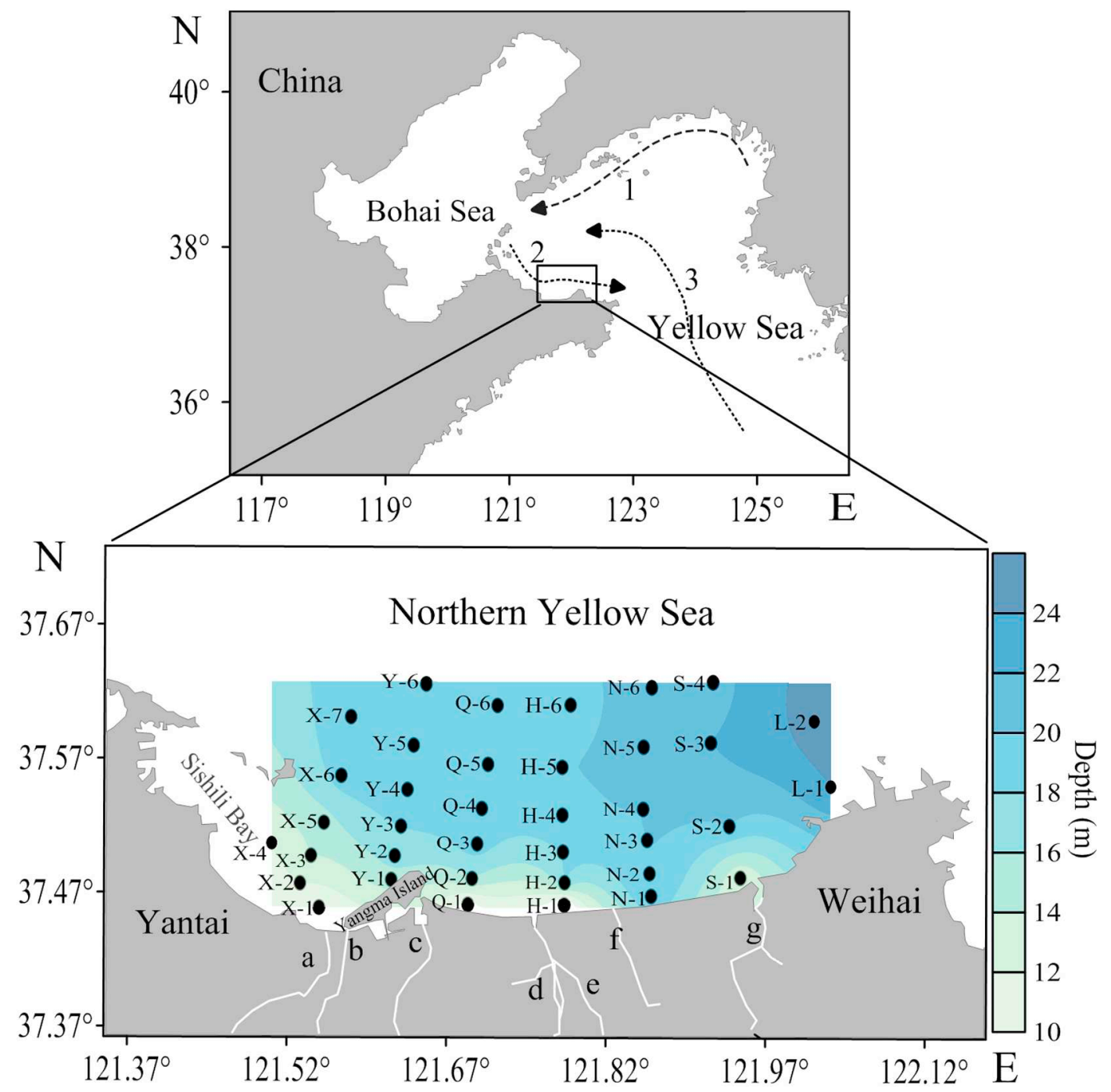

Fig. 1. Sampling sites in the coastal waters of the northern Shandong Peninsula. The a, b, c, d, e, f and g represent the Xin'an River, Yuniao River, Qinshui River, Han River, Guang River, Nian River and Yangting River, respectively. 1, 2 and 3 represent the Liaonan Coastal Current, Lubei Coastal Current and Yellow Sea Warm Current, respectively. (For interpretation of the references to color in this figure legend, the reader is referred to the Web version of this article.)

Table 1

The evaluation standards for potential eutrophication.

\begin{tabular}{|c|c|c|c|c|}
\hline Grade & Nutrient level & $\operatorname{DIN}\left(\mu \mathrm{mol} 1^{-1}\right)$ & $\operatorname{DIP}\left(\mu \mathrm{mol} \mathrm{l} 1^{-1}\right)$ & DIN/DIP \\
\hline I & Oligotrophic level & $<14.28$ & $<0.97$ & $8-30$ \\
\hline II & Moderate-level nutrient & $14.28-21.41$ & $0.97-1.45$ & $8-30$ \\
\hline III & Eutrophication & $>21.41$ & $>1.45$ & $8-30$ \\
\hline $\mathrm{IV}_{\mathrm{P}}$ & Phosphate-limiting moderate-level nutrient & $14.28-21.41$ & / & $>30$ \\
\hline $\mathrm{V}_{\mathrm{P}}$ & Phosphate moderate limiting potential eutrophication & $>21.41$ & / & $30-60$ \\
\hline $\mathrm{VI}_{\mathrm{P}}$ & Phosphate-limiting potential eutrophication & $>21.41$ & / & $>60$ \\
\hline $\mathrm{IV}_{\mathrm{N}}$ & Nitrogen-limiting moderate-level nutrient & / & $0.97-1.45$ & $<8$ \\
\hline $\mathrm{V}_{\mathrm{N}}$ & Nitrogen moderate limiting potential eutrophication & / & $>1.45$ & $4-8$ \\
\hline $\mathrm{VI}_{\mathrm{N}}$ & Nitrogen-limiting potential eutrophication & / & $>1.45$ & $<4$ \\
\hline
\end{tabular}

Table 2

General ranking for TRIX assessment.

\begin{tabular}{llll}
\hline Grade & $\begin{array}{c}\text { TRIX } \\
\text { value }\end{array}$ & Trophic status & Condition \\
\hline I & $0-4$ & Oligotrophic & Water poorly productive \\
II & $4-5$ & Mesotrophic & Water moderately productive \\
III & $5-6$ & Mesotrophic to & Water moderately to highly \\
& & eutrophic & productive \\
IV & $6-10$ & Eutrophic & Water highly productive \\
\hline
\end{tabular}

and the Yangting River, and a sewage outlet (Fig. 1). Among them, the freshwater fluxes of river was obtained by the freshwater flow rate measured using a portable flow meter (Model JCS-300A) multiplied the cross-sectional area in river mouth, while the sewage discharge data was obtained based on Bi (2006). The data of the nutrient concentrations of the Xin'an River and the Yangting River were obtained by related literature (Ma et al., 2012; Sun et al., 2016; Qin, 2018). In addition, the nutrient concentrations of the sewage, the Yuniao River and the Qinshui River were replaced by the data from the nearest sampling sites in their estuaries. The atmospheric deposition rate and adjacent 
sea inputs in this study is based on the relevant literature (Liu et al., 2003; Zhang, 2004; Bi, 2006; Song, 2009; Zhu, 2011; Hong, 2012; Han et al., 2013; Duan et al., 2016). In addition, based on the water depths of the sampling sites, the underwater terrain was simulated using the spatial interpolation and three-dimension technique provided by ArcGIS 10.5, and then acquired the sea surface area, sea floor area and water volume of the study area with the values of $664 \mathrm{~km}^{2}, 730 \mathrm{~km}^{2}$ and $12.9 \times 10^{9} \mathrm{~m}^{3}$.

\subsection{Data processing}

Contour maps for parameters (temperature, salinity, DO, Chl $a$, $\mathrm{NO}_{3}{ }^{-}, \mathrm{NO}_{2}{ }^{-}, \mathrm{NH}_{4}{ }^{+}$, DIP and DSi) were generated with the Surfer 12 (Golden Software LLC) using the Kriging method. The relationship between environmental variables (salinity, DO and Chl $a$ ) and the nutrients $\left(\mathrm{NO}_{3}{ }^{-}, \mathrm{NO}_{2}{ }^{-}, \mathrm{NH}_{4}{ }^{+}\right.$, DIP and DSi) was investigated through Pearson's correlation analysis using SPSS 19.0 software.

\section{Results}

\subsection{Hydrographic features}

Complex hydrographic conditions occurred during the study period (Fig. 2), which may influence the transport and concentration of biogenic elements. Overall, the salinity was relatively stable ranging from $31.21 \pm 0.21$ to $32.24 \pm 0.02$ (Fig. $2 \mathrm{~b}$ ), while the temperature ranged broadly from $3.1 \pm 0.4$ to $27.5 \pm 0.7^{\circ} \mathrm{C}$ (Fig. 2a). It is evident that strong temperature-induced water column stratification occurred at most sampling sites in summer (June, July and August), then weakened and eventually disappeared in autumn (September and November), which could lead to the other parameters having obvious vertical variations in summer.

DO concentrations showed clear seasonal variations, ranging from $191.3 \pm 19.4$ to $264.2 \pm 18.0 \mu \mathrm{moll}^{-1}$ in the surface water and $96.2 \pm 38.0$ to $246.5 \pm 26.4 \mu \mathrm{moll}^{-1}$ in the bottom water (Fig. $2 \mathrm{c}$ ), and the peak was observed in May 2017. As an indicator of primary production levels, Chl $a$ data were also collected in the surface water (Fig. 2d), and those values were measured at $1.08 \pm 0.80 \mu \mathrm{g} 1^{-1}$ in June 2017 to $3.28 \pm 1.83 \mu \mathrm{g} 1^{-1}$ in August 2016 .

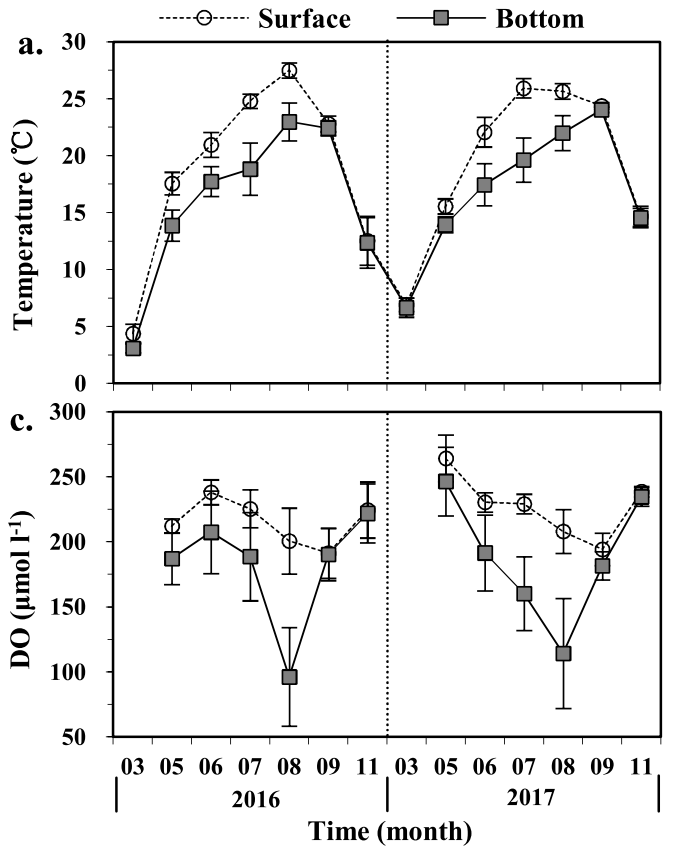

Figs. S1 and S2 show the horizontal distributions of temperature, salinity, DO and Chl $a$ in the surface and bottom waters in May, August and November 2016 and 2017. In general, human activities (e.g. domestic and industrial wastewater discharge) and runoff input can significantly affect the distribution of environmental parameters (e.g. temperature, salinity, DO and $\mathrm{Chl} a$ ) in coastal waters. During the investigation, temperature and salinity generally exhibited an obvious seaward gradient. The temperature was higher in the inshore regions than that in the offshore regions in May and August. However, relatively low temperature was observed in the west part in November (Fig. S1). Salinity could be used as a tracer of river and sewage water inputs due to its conservative mixing behavior. Salinity in August and September was lower than that in other months (Fig. 2b). Spatially, the relatively low salinity values were mainly distributed in the inshore zones; especially in August 2017 (Fig. S1s), this phenomenon was particularly evident, which could be attributed to water discharge from the nearby land because it was the rainy season. Contrary to the salinity distribution, the Chl $a$ values in the surface water generally decreased seaward in May and August in both years (Figs. S2a, b, d and e), indicating the effects of terrestrial input on the flourishing of phytoplankton.

As for DO in the bottom water, the low values were mainly found in the inshore zones in May and August (Fig. S2), and the lowest value of $55.0 \mu \mathrm{mol}^{-1}$ was recorded at the Site H-1 in August 2017. From May to August, the hypoxia spots with DO concentration falling to below $62.5 \mu \mathrm{moll} 1^{-1}$, the oxygen concentration being regarded as the level that could cause significant mortality of benthic organisms (Diaz and Rosenberg, 2008; Vaquer-Sunyer and Duarte, 2008), was formed and continued to develop (Figs. S2f, g, i and j). In November, the hypoxia phenomenon disappeared (Figs. S2h and k). It is worth noting that, in August, the relatively high Chl $a$ values in the surface water (Figs. S2b and e) appeared right in the region with low DO in the bottom water (Figs. S2g and j), which provided a clue of DO consumption resulting from organic matter degradation during an algal bloom period.

\subsection{Dissolved inorganic nutrients}

Dissolved inorganic nutrient concentrations varied considerably during the study period (Fig. 3). The DIN, DIP and DSi concentrations in

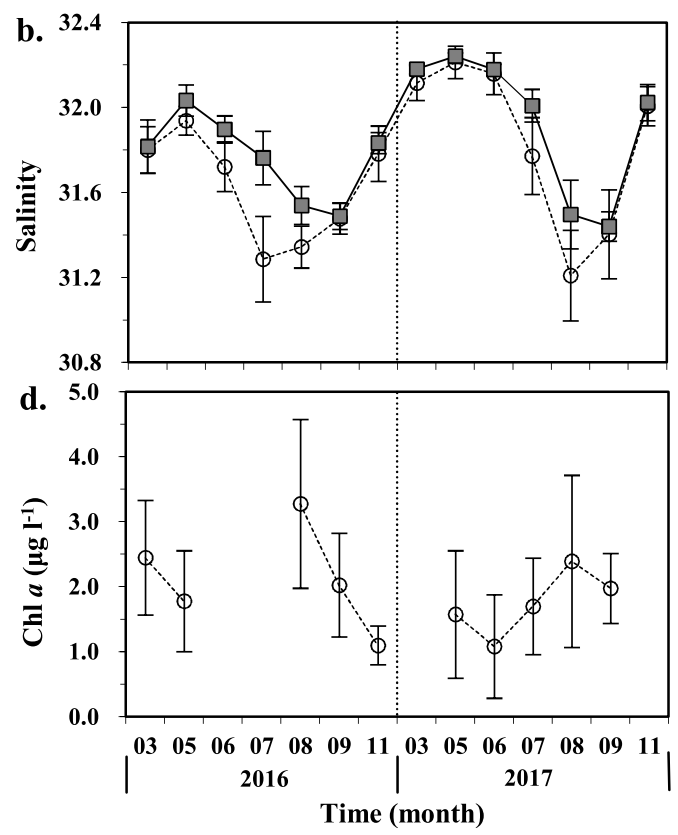

Fig. 2. The monthly mean values of temperature, salinity, Chl $a$ and DO in the surface and bottom water. 

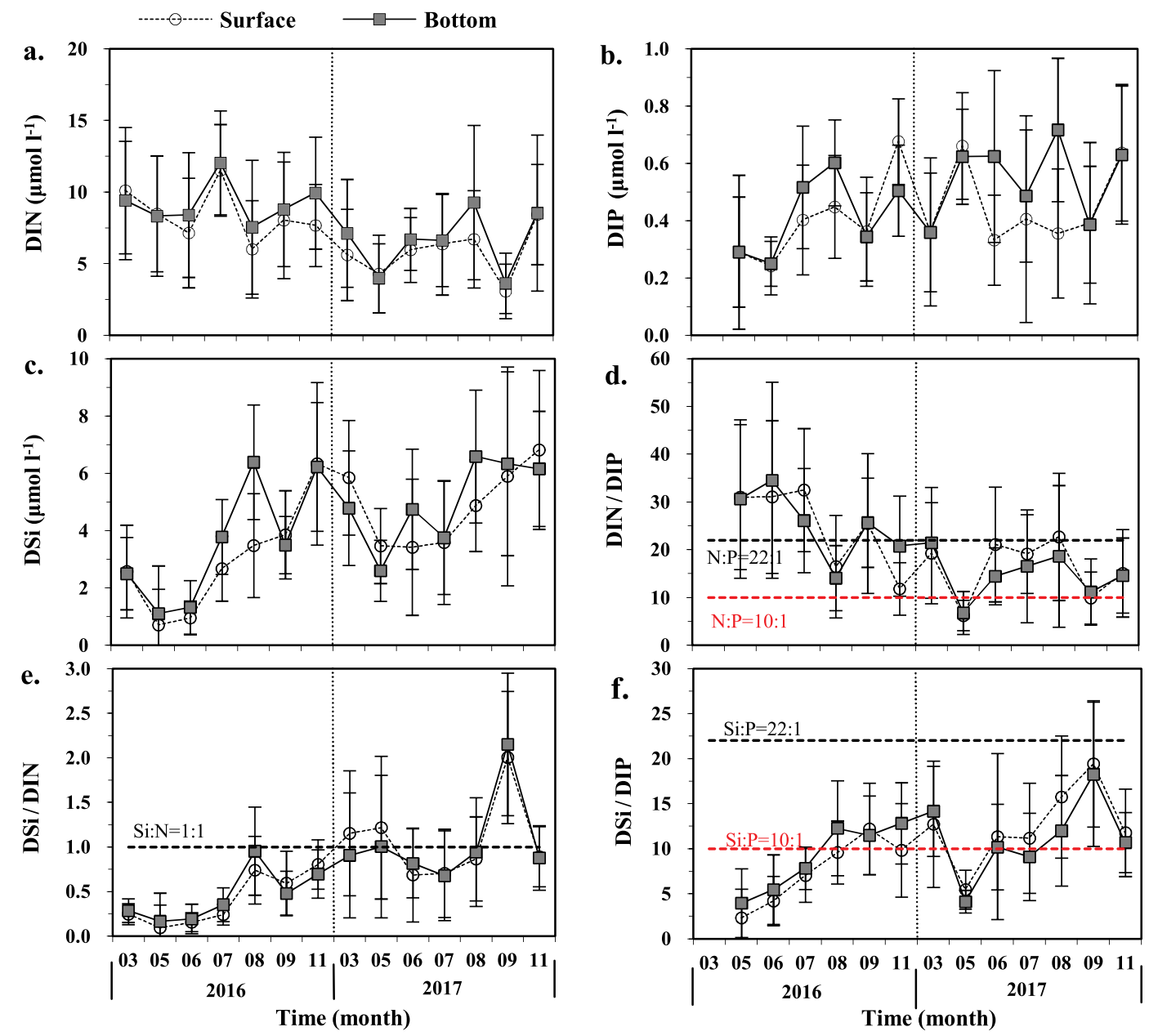

Fig. 3. The monthly mean values of DIN, DIP, DSi and nutrient ratios in the surface and bottom water.
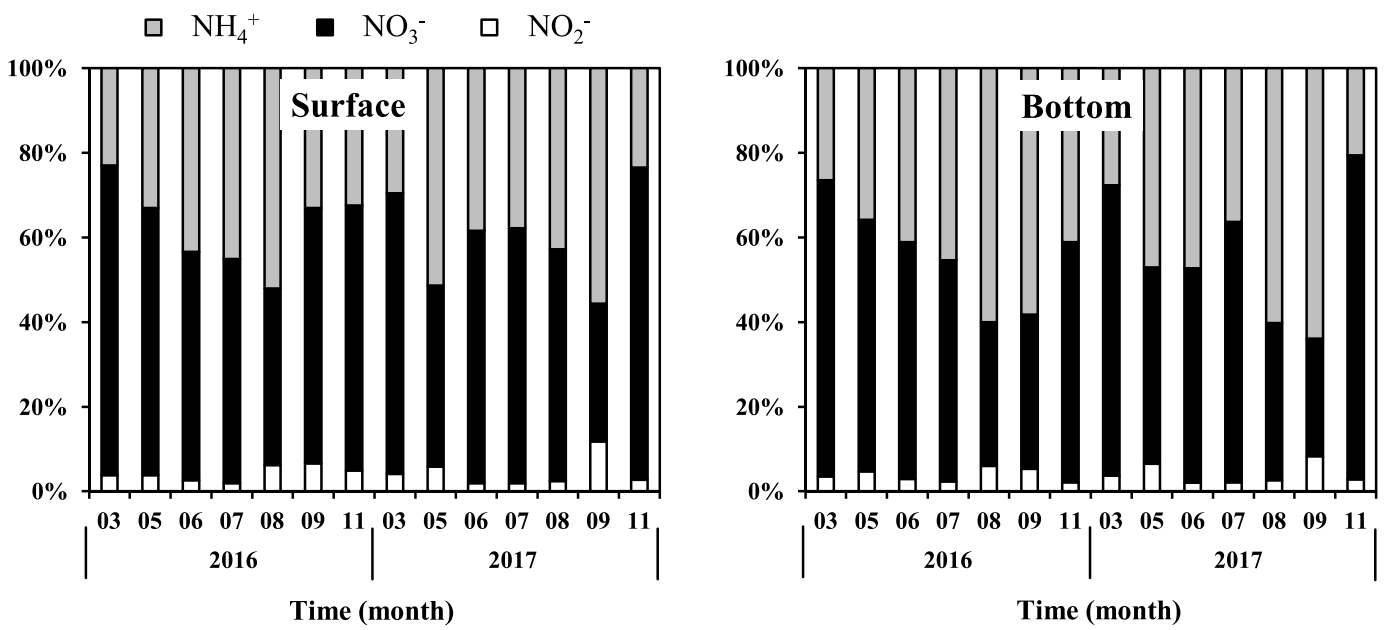

Fig. 4. The DIN composition characteristics in different months.

the surface water ranged from $3.08 \pm 1.90$ to $11.52 \pm 3.20$, $0.24 \pm 0.10$ to $0.67 \pm 0.15, \quad$ and $0.71 \pm 1.24$ to $6.82 \pm 2.77 \mu \mathrm{moll}^{-1}$, with the lowest values being observed in September 2017 for DIN, June 2016 for DIP and May 2016 for DSi, and the highest values being found in July 2016, November 2016 and November 2017. In the bottom water, the corresponding values of DIN, DIP and DSi varied from $3.63 \pm 2.11$ to $12.06 \pm 3.62,0.25 \pm 0.08$ to $0.72 \pm 0.25$ and $1.11 \pm 1.66$ to $6.58 \pm 2.32 \mu \mathrm{mol}^{-1}$; the lowest and highest values appeared in September 2017 and July 2016 for DIN, June 2016 and August 2017 for DIP, and May 2016 and August 2017 for DSi, which were different from those in the surface water. For nitrogen compounds, DIN was dominated by $\mathrm{NO}_{3}{ }^{-}$, which accounted for 28-74\% (mean 58\%) of DIN during the study period, followed by $\mathrm{NH}_{4}{ }^{+}$ (21-64\%, mean $38 \%)$, and $\mathrm{NO}_{2}{ }^{-}(2-12 \%$, mean $4.15 \%)$ was the lowest (Fig. 4). As the season progresses, the composition of DIN varied, and the proportion of $\mathrm{NO}_{3}{ }^{-}$decreased firstly and then increased, with the 
lowest values being in August-September in each year in the bottom water, while the $\mathrm{NH}_{4}{ }^{+}$value was the highest in these two months. The molar ratios of DIN/DIP, DSi/DIN and DSi/DIP varied from $6.23 \pm 3.28$ to $34.55 \pm 16.57,0.11 \pm 0.12$ to $2.15 \pm 0.80$ and $2.32 \pm 3.18$ to $19.42 \pm 7.00$, respectively, with the lowest values being found in May 2017 for DIN/DIP and May 2016 for DSi/DIN and DSi/DIP, while the highest values were observed in June 2016 for DIN/ DIP and September 2017 for DSi/DIN and DSi/DIP (Fig. 3d, e and f).

The horizontal distributions of DIN, DIP and DSi are shown in Figs. S3 and S4. During the study period, DIN was higher in the inshore zones than the offshore zones except in August 2016 and May 2017 (Figs. S3a-f and S4a-f), with the maximum value being at Site Y-1 off the Yangting River mouth in the bottom water in August 2017 (Fig. S4e), indicating the effects of terrestrial input on DIN dynamics; however, the high DIN values were mainly found in the offshore zone in August 2016 with the highest concentration of $20.5 \mu \mathrm{mol} 1^{-1}$ being recorded at Site Y-6 (Figs. S3b and S4b). As for DIP, the high values in the surface water were found in inshore zones in May and August 2016 and November 2017 (Figs. S3g and h and l), which were different from those in other months; however, in the bottom water, the high DIP values were mainly observed in the offshore zone in August and November (Figs. S4h, i, k and 1). As can be seen from Fig. S3m-r and S4m-r, the concentrations of DSi increased gradually seaward in August 2016 (Fig. S3n and S4n), which was consistent with the distribution of DIN; its concentrations had seaward decreasing trends in May and August 2017 (Fig. S3p, q and S4p, q); in other months, there was no obvious distribution pattern of DSi.

Fig. S5 shows the spatial distributions of DIN/DIP, DSi/DIN and DSi/DIP molar ratios in the surface water. In May 2016 and November 2017 (Figs. S5a and f), the values of DIN/DIP were higher in the inshore patches than the offshore patches, with the highest values being recorded at Site X-1 near the sewage outlet and the Xin'an River mouth, and its high values were mainly distributed at the spot near the Nian and Yangting River mouths in November 2016 (Fig. S5c), indicating the influence of human activities from land on DIN/DIP dynamics. However, the high values appeared in the outer parts in August 2017 (Fig. S5e), which was probably caused by microbial activity and the intrusion of water from the outside of the study area. In contrast, the values of DIN/DIP were low and varied spatially in a narrower range in May 2017 (Fig. S5d).

In May 2016, the DSi/DIN ratio was higher in the offshore zone than the inshore zone (Fig. S5g), which was contrary to that of May and August 2017 (Figs. S5j and k). However, the high values of DSi/DIN ratio were distributed in the central zone in August 2016 (Fig. S5h) and November 2017 (Fig. S51). As for DSi/DIP, the relatively high values were found in the inshore patches in May 2016 and 2017 (Fig. S5m and p) and August and November 2017 (Fig. S5q and r), which was contrary to that of August and November 2016 (Fig. S5n and o).

\section{Discussion}

\subsection{Nutrient regimes}

\subsubsection{Nutrient concentration and composition}

During the study period, nutrient concentrations presented obvious seasonal variations due to the influence of complex hydrological and biochemical conditions. According to the Standard of Seawater Quality of China GB3097-1997 (Table S1), the DIN and DIP values met the firstclass seawater standards. Table 3 summarizes the values of nutrients in some coastal waters in China. In comparison, the concentrations of DIN and DIP (Fig. 3a and b) in this study were comparable to those found in most of the coastal waters listed in Table 3, while the DSi (Fig. 3c) values were lower than those coastal waters. In addition, the spatial variations of dissolved inorganic nutrients were relatively insignificant in different months, which could be influenced by multiple factors, such as terrestrial and adjacent sea inputs, phytoplankton reproduction and

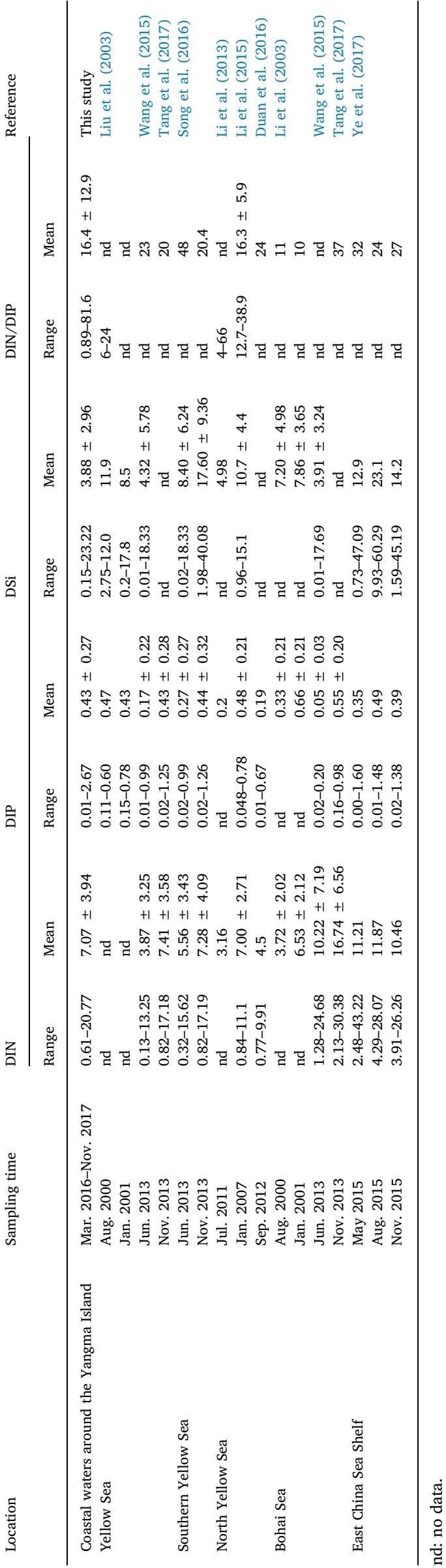


organic matter decomposition (Hao, 2010; Cui et al., 2013).

The nutrient concentrations and their molar ratios have an important impact on the growth, reproduction and species composition of the phytoplankton, because different algal species have different requirements for nutrients (Yunev et al., 2007). Studies of nutrient uptake kinetics have shown that the threshold values for phytoplankton growth are $\mathrm{DIN}=1 \mu \mathrm{mol} 1^{-1}$, DIP $=0.1 \mu \mathrm{moll}^{-1}, \mathrm{DSi}=2 \mu \mathrm{moll}^{-1}$ (Nelson and Brzezinski, 1990; Justi et al., 1995). Based on these threshold values, the DSi was the most limiting element for phytoplankton growth in May and June 2016.

As for nutrient ratios, they could be used to infer the potential nutrient limitation, as well as changes in the phytoplankton community assemblage (Santos and Eyre, 2013; Fan et al., 2014; Wang et al., 2014). It is well known that $\mathrm{N}$ and $\mathrm{P}$ enrichment may lead to deficiency of dissolved $\mathrm{Si}$, hence, limit diatom growth, and result in food web changes in aquatic systems (Humborg et al., 2000; Samuelsson et al., 2002). In addition, when $P$ is deficient and $N$ is sufficient, the dominant species of phytoplankton communities readily change from diatoms to dinoflagellates (Richardson, 1997; Conley et al., 2008). Based on previous research (Nelson et al., 1990; Dortch et al., 1992), Justic et al. (1995) proposed a criterion for evaluating the growth limitation of each nutrient to primary producers in coastal waters: if DSi/DIP > 22, DIN/ DIP $>22$, P would be the limiting nutrient; if DIN/DIP $<10, \mathrm{DSi}$ / DIN $>1, N$ would be the limiting nutrient; and if DSi/DIP $<10, \mathrm{DSi} /$ DIN $<1$, then $\mathrm{Si}$ would be the limiting nutrient. In this study, the growth of phytoplankton was potentially limited by $\mathrm{P}$ and Si from May to June 2016, while it was potentially limited by P in November 2016. In May 2017, $\mathrm{N}$ obviously stimulated the phytoplankton growth. However, no potential nutrient limitation was observed in other months (Fig. 3d, e and f).

\subsubsection{Potential eutrophication assessment model and trophic index}

In order to highlight the limiting characteristics of nutrients, the potential eutrophication evaluation model proposed by Guo et al. (1998) was used for the evaluation of the nutritional status in the study area (Table 1). The results showed that the surveyed area was characterized by oligotrophic level, which was basically consistent with the relevant research results in Xing et al. (2013).

In this study, the values of TRIX ranged from 2.64 to 6.28 with an average of 4.57, which was comparable to the values reported for other marine areas listed in Table 4. The seasonal maximum value 5.07 was obtained in November 2016 and the minimum value 4.03 was obtained in June 2017 (Fig. 5). Overall, the trophic status was rated at the medium level, characterized by moderately productive waters (Fig. 5). Spatially, the trophic status showed a clear variation (Fig. S6). In May 2016 and August 2017 (Figs. S6a and d), the TRIX values were generally high in the inshore patches, indicating the relatively poor water quality, which could be attributed to the great influence from human activities (Han and Liu, 2014). In contrast, the TRIX values were higher

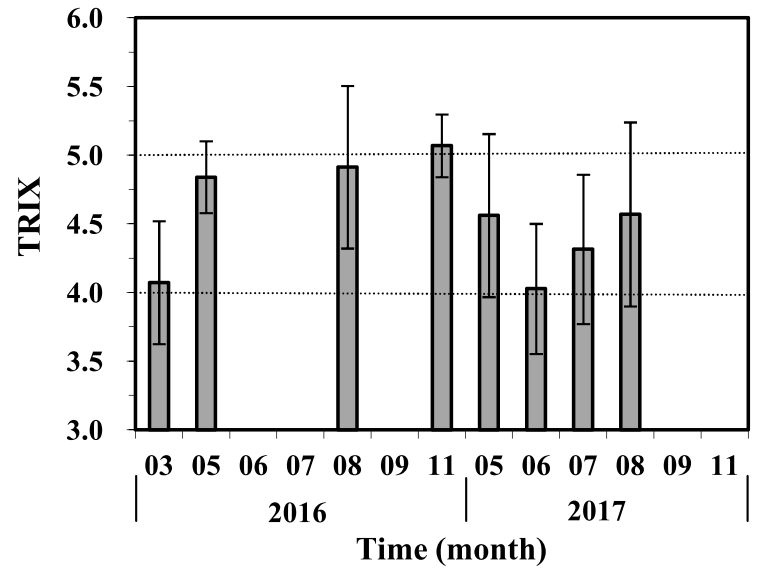

Fig. 5. TRIX index values in the surface water in different months.

in the offshore regions than the inshore regions in other months (Fig. S6b, c and e).

\subsection{Factors influencing the seasonal nutrient variations}

From March 2016 to November 2017, the concentrations of DIN, DIP and DSi varied spatially and temporally (Fig. 3), which were essentially attributed to the differences in sources and consumption of nutrients. The sources of nutrients to the coastal waters of the northern Shandong Peninsula mainly include river and sewage inputs, atmospheric deposition, the adjacent sea input and biological input, while the uptake by algae and removal by scallop harvest may be responsible for the decrease in dissolved nutrients.

\subsubsection{River and sewage inputs}

In the study area, there are several small seasonal rivers along the coastline, and a sewage outlet is located near the sampling site X-1, with the total freshwater fluxes of $\sim 89.5 \times 10^{6} \mathrm{~m}^{3} \mathrm{yr}^{-1}$ (Table 5), accounting for $0.7 \%$ of the total volume of seawater, which could play a significant role in nutrient dynamics in the surface water.

As shown in Fig. 6, there were significant positive linear relationships between salinity and DIN in the surface water in May and November $2016\left(\mathrm{R}^{2}=0.328, P<0.01 ; \mathrm{R}^{2}=0.173, P<0.05\right)$ and May $2017\left(\mathrm{R}^{2}=0.436, P<0.001\right)$. For the DIN constituents, there were significant positive linear relationships between salinity and $\mathrm{NO}_{3}{ }^{-}$in the surface water in November $2016\left(\mathrm{R}^{2}=0.128, P<0.05\right)$ and May, August and November $2017\left(\mathrm{R}^{2}=0.714, P<0.001 ; \mathrm{R}^{2}=0.165\right.$, $P<0.05 ; \mathrm{R}^{2}=0.502, P<0.001$ ) (Fig. 6d and Table S2). However, no significant correlation between salinity and $\mathrm{NH}_{4}{ }^{+}$and $\mathrm{NO}_{2}{ }^{-}$was found in this study. As for salinity and DSi, there were significant positive linear relationships in August 2016 and $2017\left(R^{2}=0.367\right.$,

Table 4

The values of TRIX in this study and some other seas.

\begin{tabular}{|c|c|c|c|c|}
\hline \multirow[t]{2}{*}{ Location } & \multirow[t]{2}{*}{ Sampling time } & \multicolumn{2}{|l|}{ TRIX } & \multirow[t]{2}{*}{ Reference } \\
\hline & & Range & Mean & \\
\hline Coastal waters around the Yangma Island & Mar. 2016-Nov. 2017 & $2.64-6.28$ & 4.57 & This study \\
\hline \multirow[t]{2}{*}{ Yellow and East China Seas } & Jul. 2013 & $2.66-7.32$ & 5.65 & Sun and Su (2016) \\
\hline & Jun. and Nov. 2013 & $3.87-7.32$ & 5.68 & Liu (2015) \\
\hline Yellow and Bohai Sea & Jun. and Nov. 2013 & $3.03-6.72$ & 5.62 & Liu (2015) \\
\hline East China Sea & Jul. 2013 and Jun. 2014 & $3.87-6.79$ & 5.39 & Liu (2015) \\
\hline Black Sea & 1995 & $3.7-8.6$ & nd & Moncheva et al. (2001) \\
\hline Caspian Coast & 1982-1993 & $4.04-6.08$ & nd & Shahrban and Etemadshahidi (2010) \\
\hline Gulf of Mexico & 2002-2006 & $2.41-6.02$ & nd & Herrera-Silveira and Morales-Ojeda, (2009) \\
\hline Tyrrhenian Sea & 2000 & nd & 4.17 & Giovanardi and Vollenweider (2004) \\
\hline Italian Coast & $2001-2003$ & $2.99-6.03$ & nd & Pettine (2007) \\
\hline
\end{tabular}

nd: no data. 


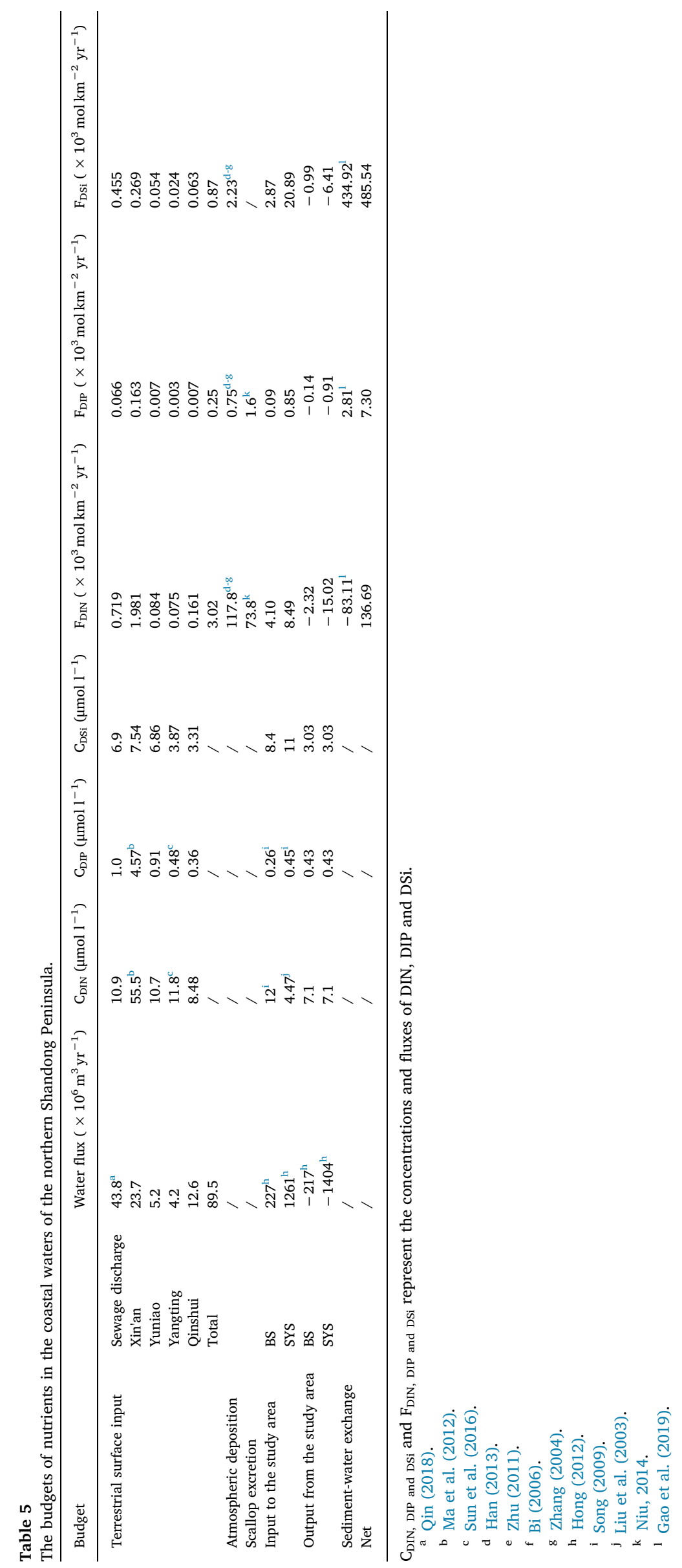



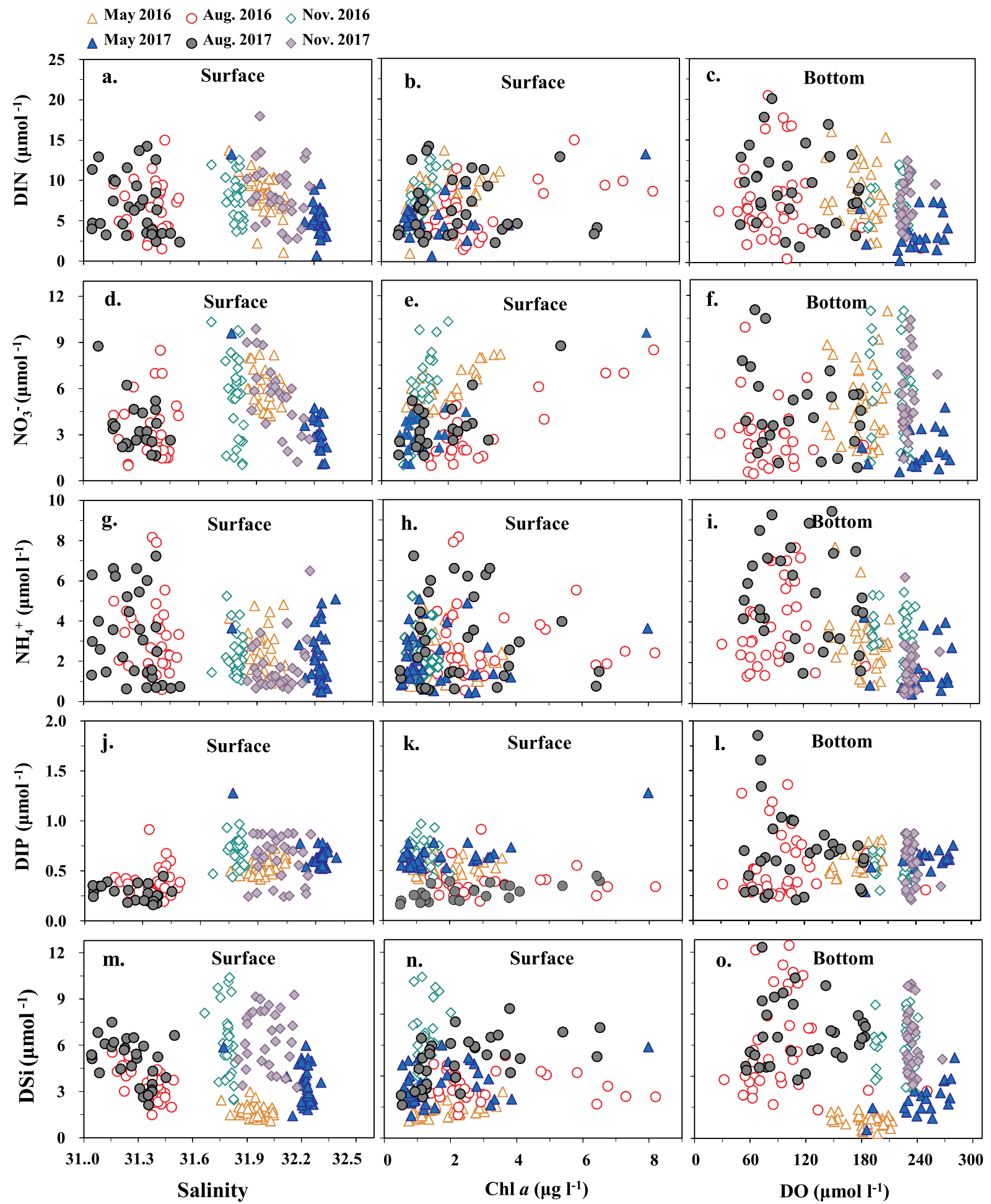

Fig. 6. Scatter plots of nutrients vs. the salinity, Chl $a$ and DO.

$P<0.01 ; \mathrm{R}^{2}=0.335, P<0.01$ ) (Fig. $6 \mathrm{~m}$ and Table S2). However, DIP had no significant correlation with salinity in all months. These demonstrate that the river/sewage inputs could be a main factor in the spatial variation of $\mathrm{NO}_{3}{ }^{-}$and $\mathrm{DSi}$, while they had a weak influence on the spatial variation of DIP.

The terrestrial surface input of dissolved nutrients can be estimated by the annual total river water and sewage discharge with nutrient concentrations. Nutrient concentrations vary considerably, depending on specific streams and forms of nutrients. Given that the rivers are characterized by seasonal freshwater discharge and anthropogenic disturbance, there could be a great uncertainty in the estimation of annual nutrient input from land (Liu et al., 2005). Generally, the local rainfall is the main factor affecting the freshwater fluxes. In recent years, the average annual rainfall in study area is $\sim 764 \mathrm{~mm}$, of which $\sim 70 \%$ occurs between June and September (http://www.muping.gov.

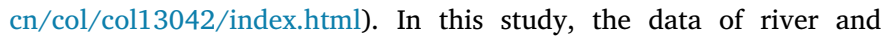
sewage discharge was obtained from March to November (Table 5). Based on these data, the terrestrial surface inputs of DIN, DIP and DSi 
were estimated to be $3.02 \times 10^{3}, 0.25 \times 10^{3}$ and $0.87 \times 10^{3} \mathrm{~mol} \mathrm{~km}^{-2}$ $\mathrm{yr}^{-1}$, respectively. Among them, the input of the Xin'an River and the sewage was dominant, accounting for $65.6 \%$ and $23.8 \%$ for DIN, $66.2 \%$ and $26.8 \%$ for DIP and $31.1 \%$ and $52.6 \%$ for DSi of the total flux, respectively.

In recent decades, submarine groundwater discharge (SGD) has been found to be an important channel for the supply of dissolved nutrients in some marine areas (Slomp and Van Cappellen, 2004; Lee et al., 2009; Rodellas et al., 2015; Cho et al., 2018). The relationships between salinity and the measured nutrient parameters in the bottom water indicated that the salinity had no significant correlation with nutrients in all months except March 2016 (Table S2). So SGD may be a minor influencing factor in the biogeochemistry of nutrients in this area. Besides, data about SGD were completely unavailable in this study area because no related research was carried out, therefore the influence of SGD on the nutrient biogeochemistry was not included in this study.

\subsubsection{Atmospheric deposition}

Atmospheric deposition is important not only because of its magnitude, but also because the mix of atmospheric nutrients, like other nutrient sources, can stimulate the disproportionate growth of some phytoplankton species over others (Zhang et al., 2007). Experimental manipulations have shown that the rainwater can enhance primary productivity more than the addition of a single form of nitrogen (Paerl, 1997). The high proportion of DON in rainwater, accounting for up to $40 \%$ of its total $\mathrm{N}$, is thought to be significant in this enhancement (Paerl, 1997).

Algal blooms in the Yellow Sea of China, which have escalated in frequency over the past several decades, have been reported to be related to atmospheric deposition in addition to direct nutrient runoff (Zhang, 1994). It is estimated that a typical rain event over the Yellow Sea may supply sufficient N, P and Si to account for $50-100 \%$ of the primary production of an algal bloom event (Zhang, 1994). Chung et al. (1998) showed that the contribution of atmospheric nitrogen might account for $17-37 \%$ of the nitrate requirement for annual new production in the Yellow Sea. For external sources (riverine and atmospheric inputs), Liu et al. (2003) indicated that atmospheric input supplied $93 \%$ of $\mathrm{NH}_{4}{ }^{+}$and $68 \%$ of DIP for the Yellow Sea. Han et al. (2013) estimated that atmospheric depositions of $\mathrm{NH}_{4}{ }^{+}$, DIN, DSi and DIP accounted for $87 \%, 47 \%, 3 \%$ and $53 \%$ of external sources (atmospheric depositions and riverine influx), respectively. According to the results in relevant literature (Zhang, 2004; Bi, 2006; Zhu, 2011; Han et al., 2013; Duan et al., 2016), the total nutrient fluxes in this study area from atmospheric deposition were estimated to be $117.8 \times 10^{3}$, $0.75 \times 10^{3}$ and $2.23 \times 10^{3} \mathrm{~mol} \mathrm{~km}^{-2} \mathrm{yr}^{-1}$ for DIN, DIP and DSi (Table 5).

\subsubsection{Inputs from the adjacent seas}

The study area is located in the southwest of the NYS. The nutrients can be transported from the BS to the NYS by the Lubei Coastal Current (Fig. 1), whereas exchange between the NYS and the SYS is through the Yellow Sea Warm Current. The input flux of seawater from the BS to the NYS was $52.2 \times 10^{9} \mathrm{~m}^{3} \mathrm{yr}^{-1}$ (Hong, 2012). The water volume in the study area is about $12.9 \times 10^{9} \mathrm{~m}^{3}$, accounting for $\sim 1 / 230$ of the volume of the entire NYS. It was assumed that the seawater in the NYS was evenly distributed, and the seawater flux from the BS into the research area was about $2.27 \times 10^{8} \mathrm{~m}^{3} \mathrm{yr}^{-1}$. The mean DIN, DIP and DSi concentrations in the BS water, namely $12,0.26$ and $8.4 \mu \mathrm{mol}^{-1}$ (Song, 2009; Zhou et al., 2017), were used for the calculation of the dissolved nutrient influxes from the BS to the study area and the results were $4.10 \times 10^{3}, 0.09 \times 10^{3}$ and $2.87 \times 10^{3} \mathrm{~mol} \mathrm{~km}^{-2} \mathrm{yr}^{-1}$ for DIN, DIP and DSi, respectively (Table 5). Another major sea input to the study area was SYS. The input flux of seawater from the SYS to the study area was estimated to be $12.61 \times 10^{8} \mathrm{~m}^{3} \mathrm{yr}^{-1}$ (Hong, 2012). The mean DIN, DIP and DSi concentrations in the SYS of 4.47, 0.45 and
$11 \mu \mathrm{mol}^{-1}$ (Liu et al., 2003; Song, 2009; Yu, 2014) were used to calculate the dissolved nutrient influxes from the SYS to the study area and the results were $8.49 \times 10^{3}, 0.85 \times 10^{3}$ and $20.89 \times 10^{3} \mathrm{~mol} \mathrm{~km}^{-2}$ $\mathrm{yr}^{-1}$ for DIN, DIP and DSi, respectively (Table 5).

The output flux of seawater from the study area to the BS and the SYS were estimated to be $2.17 \times 10^{8}$ and $14.04 \times 10^{8} \mathrm{~m}^{3} \mathrm{yr}^{-1}$ (Hong, 2012). The mean DIN, DIP and DSi concentrations throughout the investigation in the study area, namely 7.1, 0.43 and $3.03 \mu \mathrm{mol}^{-1}$, were used for the calculation of the dissolved nutrient outputs from the study area to the BS and the SYS. The results indicated that $2.32 \times 10^{3} \mathrm{~mol} \mathrm{~km}^{-2} \quad$ DIN, $0.14 \times 10^{3} \mathrm{~mol} \mathrm{~km}^{-2} \quad$ DIP and $0.99 \times 10^{3} \mathrm{~mol} \mathrm{~km}^{-2}$ DSi could be transported from the study area to the BS each year and $15.02 \times 10^{3} \mathrm{~mol} \mathrm{~km}^{-2}$ DIN, $0.91 \times 10^{3} \mathrm{~mol} \mathrm{~km}^{-2}$ DIP and $6.41 \times 10^{3} \mathrm{~mol} \mathrm{~km}^{-2}$ DSi could be transported from the study area to the SYS each year (Table 5). Therefore, in the process of exchange with the BS and the SYS, the study area was a net output of DIN and DIP and their fluxes were $4.75 \times 10^{3}$ and $0.11 \times 10^{3} \mathrm{~mol} \mathrm{~km}^{-2}$ $\mathrm{yr}^{-1}$, respectively. However, it was a net input of DSi with a flux of $16.36 \times 10^{3} \mathrm{~mol} \mathrm{~km}^{-2} \mathrm{yr}^{-1}$.

\subsubsection{Regeneration of nutrients by respiratory activity}

The regeneration of nutrients by the respiratory activity of marine organisms is also a process of critical importance to the maintenance of life in the sea (DePinto et al., 1977). It is axiomatic that when algal cells die and are decomposed, some nutrients are released to the surrounding environment. Along with many other biogeochemical processes, this process can have a marked effect on the dynamic seasonal succession of phytoplankton as well as the total biomass at any point.

The simplest model for nutrient regeneration is the stoichiometric model. Models of this type have been successfully applied to the study of the ocean by Redfield (1963) to describe the aerobic decomposition of marine plankton, which is a complex process that involves physical, chemical and biological interactions. When the process as a whole reaches its thermodynamic reaction balance, the chemical composition concerned can be expressed as $\left(\mathrm{CH}_{2} \mathrm{O}\right)_{106}\left(\mathrm{NH}_{3}\right)_{16} \mathrm{H}_{3} \mathrm{PO}_{4}+138 \mathrm{O}_{2} \rightarrow$ $106 \mathrm{CO}_{2}+122 \mathrm{H}_{2} \mathrm{O}+16 \mathrm{HNO}_{3}+\mathrm{H}_{3} \mathrm{PO}_{4}$. If $\mathrm{O}_{2}$ is available, the most important respiration process is aerobic or via $\mathrm{O}_{2}$ consumption, and the equation predicts that the consumption of 276 oxygen atoms results in the production of 16 nitrogen atoms, and 1 phosphorus atom. However, if $\mathrm{NH}_{4}{ }^{+}$is the end product, aerobic decomposition of organic matter, i.e. $\left(\mathrm{CH}_{2} \mathrm{O}\right)_{106}\left(\mathrm{NH}_{3}\right)_{16} \mathrm{H}_{3} \mathrm{PO}_{4}+106 \mathrm{O}_{2} \rightarrow \mathrm{CO}_{2}+108 \mathrm{H}_{2} \mathrm{O}+$ $16 \mathrm{NH}_{3}+\mathrm{H}_{3} \mathrm{PO}_{4}$, results in the consumption of every 212 oxygen atoms for the generation of 16 nitrogen atoms and 1 phosphorus atom (Alvarez-Borrego et al., 1975). For the evaluation of the in situ production rate of nutrients from the respiration process, the relationships between nutrients and DO in the bottom water were discussed in this study.

Fig. 6 shows the relationship between DO and nutrients in the bottom waters in different seasons. In the present study, no significant correlations were found between DO and nutrients, which could be explained by the following two reasons. First, some of the nutrient ions formed by bacteria decomposition were adsorbed on suspended particulate solids and thus did not appear in the solution (Stevenson and Cheng, 1972); second, the complex biomineralization process yielded much organic nutrients instead of inorganic nutrients (Qualls and Richardson, 2003; Jone et al., 2004).

\subsubsection{Nutrient uptake by phytoplankton}

Phytoplankton is the most important nutrient consumer in the sea, which transforms dissolved nutrients into particulate matter (Cowan and Boynton, 1996). In this research, the monthly mean value of Chl $a$ in the surface water increased from spring to summer with the highest value of $8.19 \mu \mathrm{g}^{-1}$ being recorded in August 2016, and then decreased from summer to autumn with the lowest value of $0.51 \mu \mathrm{g} \mathrm{l}^{-1}$ being recorded in November 2016 (Fig. S2). For the nutrients, overall, the highest values of DIN, DIP and DSi were observed in autumn and the 


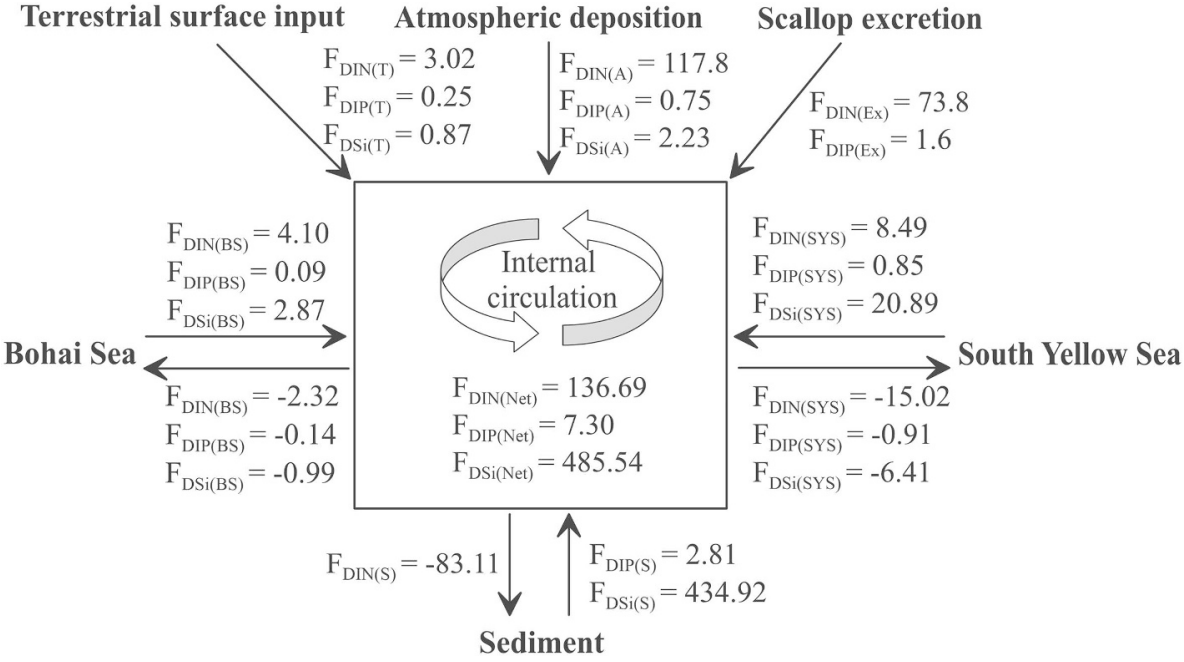

Fig. 7. Box model showing the nutrient budgets of the coastal waters of the northern Shandong Peninsula. The positive and negative values indicate the input and output of nutrient to the system, respectively $\left(\times 10^{3} \mathrm{~mol} \mathrm{~km}^{-2} \mathrm{yr}^{-1}\right)$. Subscripts $\mathrm{T}, \mathrm{A}$, $\mathrm{Ex}, \mathrm{BS}, \mathrm{SYS}$ and $\mathrm{S}$ represent the terrestrial surface input, atmospheric deposition, scallop excretion, Bohai Sea, South Yellow Sea and sediment. lowest values of them were recorded in summer (Fig. 3), reflecting that the phytoplankton reproduction significantly affected the nutrient concentrations (Cowan and Boynton, 1996).

Spatially, there were significant linear relationships between Chl $a$ and DIN in the surface water in May, August and November 2016 $\left(\mathrm{R}^{2}=0.126, \quad P<0.05 ; \quad \mathrm{R}^{2}=0.292, \quad P<0.05 ; \quad \mathrm{R}^{2}=0.603\right.$, $P<0.001)$ and May $2017\left(\mathrm{R}^{2}=0.292, P<0.05\right)$ (Fig. 6b; Table S2). For Chl $a$ and $\mathrm{NO}_{3}{ }^{-}$, significant linear relationships between them were observed in the surface water in May, August and November 2016 $\left(\mathrm{R}^{2}=0.631, \quad P<0.001 ; \quad \mathrm{R}^{2}=0.731, \quad P<0.001 ; \quad \mathrm{R}^{2}=0.621\right.$, $P<0.001)$ and May and August $2017\left(\mathrm{R}^{2}=0.670, P<0.001\right.$; $\mathrm{R}^{2}=0.444, P<0.001$ ) (Fig. 6e; Table S2), indicating the promoting effect of nitrate on the growth of phytoplankton in these months.

In addition, DIP had significant linear relationships with Chl $a$ in May and August $2017 \quad\left(\mathrm{R}^{2}=0.564, \quad P<0.001 ; \quad \mathrm{R}^{2}=0.469\right.$, $P<0.001$ ) (Fig. 6k; Table S2). For Chl $a$ and DSi, there were significant linear relationships for them in May and November 2016 $\left(\mathrm{R}^{2}=0.324, P<0.001 ; \mathrm{R}^{2}=0.259, P<0.001\right)$ and May and August $2017\left(\mathrm{R}^{2}=0.121, P<0.05 ; \mathrm{R}^{2}=0.291, P<0.01\right)$ (Fig. 6n; Table S2), reflecting the promoting effect of DSi on the growth of phytoplankton.

\subsubsection{Effects of scallop culture on nutrient biogeochemical cycles}

Chlamys farreri, an important edible bivalve species also known as the Chinese scallop, is the most aquacultured species in this region, and the cultivation method is mainly raft culture, which covers an area of about $150 \mathrm{~km}^{2}$, namely $\sim 23 \%$ of the surface area of the study area. Such large-scale scallop aquaculture inevitably has a significant impact on the concentration and structure of nutrients. On one hand, a large amount of $\mathrm{N}$ and $\mathrm{P}$ can be removed through bivalve harvesting (Troell et al., 2009). Zhou et al. (2002) estimated that a total of $600 \mathrm{t} \mathrm{yr}^{-1}$ of $\mathrm{N}$ and $39.4 \mathrm{tyr}^{-1}$ of $\mathrm{P}$ were removed by scallop production in the Sishili Bay, which is next to the west of the study area (Fig. 1). On the other hand, bivalve aquaculture plays a major role in nutrient regeneration in coastal ecosystems, provides essential needs for primary producers through rapid and efficient recycling of inorganic $\mathrm{N}$ and $\mathrm{P}$ and increases the risk of harmful algal blooms at local scales (Magni et al., 2000; Pietros and Rice, 2003; Newell, 2004). Cui et al. (2005) reported that, during summer, about $3.36 \mathrm{t}$ of $\mathrm{NH}_{4}{ }^{+}$and $0.42 \mathrm{t}$ of DIP were released through bivalve excretion in the Sishili Bay. Li et al. (2016) estimated that a total of $11.7 \times 10^{6}$ and $0.68 \times 10^{6} \mathrm{~mol}$ of DIN and DIP were excreted by shellfish each year in the Sanggou Bay, China.

According to the survey results in Niu (2014), the amounts of DIN and DIP excreted by scallops were about 2.48 and $0.049 \mu \mathrm{mol}$ ind $^{-1}$ $\mathrm{h}^{-1}$. In general, the growth cycle of scallops is about 200 days, which is from May to November. In addition, the annual production of scallops in the surveyed area is $\sim 1.2 \times 10^{5}$ tons (http://tjj.yantai.gov.cn/col/ col118/index.html), about $5 \times 10^{9}$ ind. Based on these data, the total amounts of DIN and DIP excreted by scallops in the study area were estimated to be $73.8 \times 10^{3}$ and $1.6 \times 10^{3} \mathrm{~mol} \mathrm{~km}^{-2} \mathrm{yr}^{-1}$, respectively. Compared with the terrestrial surface input and atmospheric deposition, scallop excretion was the main source of DIP in the study area.

\subsubsection{Exchange fluxes of nutrients between sediment-water interface}

Exchange of nutrients between sediment-water interfaces is one of the important ways for the supply and removal of nutrients in seawater (Liu et al., 2003, 2005). Zhao et al. (2016) reported that about $350 \times 10^{9} \mathrm{~mol} \mathrm{yr}^{-1}$ of DIN and $0.96 \times 10^{9} \mathrm{~mol} \mathrm{yr}^{-1}$ of DIP were released from sediment in the Yellow and Bohai Seas, which provides a significant source of nutrients for the overlying water to support primary production. Liu et al. (2003) found that sediment release was the main source of $\mathrm{NO}_{3}{ }^{-}$and DSi in the Yellow Sea, which accounted for $83.6 \%$ and $85.0 \%$ of total nutrient input, including river input, atmospheric deposition and sediment-sea exchange.

The exchange fluxes of nutrients between sediment and the overlying seawater in the study area were determined by Gao (2019) based on incubation experiments, and the benthic nutrient fluxes are shown in Table 5. The results indicated that sediment was a source for DIP and DSi, with the fluxes of $2.81 \times 10^{3}$ and $434.92 \times 10^{3} \mathrm{~mol} \mathrm{~km}^{-2} \mathrm{yr}^{-1}$, respectively; however, it was a sink for DIN, with the flux of $83.11 \times 10^{3} \mathrm{~mol} \mathrm{~km}^{-2} \mathrm{yr}^{-1}$. Compared with the terrestrial surface input, atmospheric deposition and scallop excretion, sediment release was the main source of DIP and DSi supplementation.

\subsubsection{The budgets of dissolved $N, P$ and $\mathrm{Si}$}

A steady-state box model based on the LOICZ approach (Gordon et al., 1996) was used for the construction of the nutrient budgets from non-conservative distributions of nutrients and water budgets. The data of terrestrial surface input (sewage outlet, Xin'an River, Yuniao River, Qinshui River and Yangting River), atmospheric deposition, exchanges with the BS and the SYS, scallop excretion and exchanges across the sediment-water interface (Table 5; Fig. 7) were included in the mass balance calculation of dissolved N, P and Si.

For all inputs, DIN load was mainly from atmospheric deposition and scallop excretion which accounted for $56.9 \%$ and $35.6 \%$, respectively. DIP was mainly from scallop excretion and sediment release, which contributed to $25.2 \%$ and $44.3 \%$ of the total input. For DSi, sediment release was the main source, accounting for $94.2 \%$ (Table 5; Fig. 7). In addition, about $136.7 \times 10^{3} \mathrm{~mol} \mathrm{~km}^{-2} \mathrm{yr}^{-1}$ of DIN, $7.3 \times 10^{3} \mathrm{~mol} \mathrm{~km}^{-2} \mathrm{yr}^{-1}$ of DIP and $485.5 \times 10^{3} \mathrm{~mol} \mathrm{~km}^{-2} \mathrm{yr}^{-1}$ of DSi could be converted into other forms, e.g. organic and particulate matter and gas species. 


\section{Conclusions}

Exploring the biogeochemical cycle of nutrients in the coastal waters is an important step toward understanding the regional material cycling and environmental evolution and protection. This study focused on the concentrations, compositions, behavior, and biogeochemical dynamics of dissolved nutrients in a seasonally hypoxia-influenced coastal water ecosystem from March 2016 through November 2017. The results indicated that the concentrations of DIN, DIP and DSi generally presented significant seasonal variations and were the highest in July 2016 for DIN and November 2016 for DIP and DSi. For nitrogen compounds, DIN was mainly dominated by $\mathrm{NO}_{3}{ }^{-}$, which accounted for $28-74 \%$ (mean 58\%) of DIN during the study period, followed by $\mathrm{NH}_{4}{ }^{+}$ $(21-64 \%$, mean $38 \%)$. As a whole, in the study area, the growth of the phytoplankton from May to June 2016 was potentially limited by P and $\mathrm{Si}$, the growth of phytoplankton in November 2016 was potentially limited by $\mathrm{P}$, while $\mathrm{N}$ could obviously stimulate the phytoplankton growth in May 2017. The results of nutrient budgets showed that human activities play an important role in the biogeochemistry of DIN and DIP, but have a little impact on that of DSi. In addition, massive scallop farming, which transformed huge amount of dissolved inorganic nutrients uptaken by primary producers into seafood and other particulate and dissolved organic matter, could be to a large extent favorable for the oligotrophic condition of seawater in this area, yet this was not quantitatively analyzed in present study. Therefore, further studies taking more factors into account are needed for a better understanding of the nutrient cycle in this area.

\section{Declaration of competing interest}

We declare that we have no conflicts of interest to this work.

\section{Acknowledgments}

This work was financially supported by the Strategic Priority Research Program of the Chinese Academy of Sciences (XDA23050303). The assistance of Dr. Yong Zhang and Dr. Kai Liu in the sample collection and laboratory work is greatly appreciated.

\section{Appendix A. Supplementary data}

Supplementary data to this article can be found online at https:// doi.org/10.1016/j.marpolbul.2019.110693.

\section{References}

Alvarez-Borrego, S., Guthrie, D., Culberson, C.H., Park, P.K., 1975. Test of Redfield's model for oxygen-nutrient relationships using regression analysis. Limnol. Oceanogr. 20 (5), 795-805.

Anderson, T.H., Taylor, G.T., 2001. Nutrient pulses, plankton blooms, and seasonal hypoxia in western Long Island Sound. Estuaries 24 (2), 228-243.

Asanuma, I., Zhang, X.G., Zhao, C., Huang, B., Hasegawa, D., 2014. Nutrients distribution in the coastal water of East Asia relative to the Kuroshio. Landsc. Ecol. Eng. 10 (1), 191-199.

Aydin-Onen, S., Kocak, F., Kucuksezgin, F., 2012. Evaluation of spatial and temporal variations of inorganic nutrient species in the eastern Aegean Sea waters. Mar. Pollut. Bull. 64 (12), 2849-2856.

Barbiero, R.P., Lesht, B.M., Warren, G.J., Rudstam, L.G., Watkins, J.M., Reavie, E.D., Karatayev, A.Y., 2018. A comparative examination of recent changes in nutrients and lower food web structure in Lake Michigan and Lake Huron. J. Great Lakes Res. 44 (4), 573-589.

Bi, Y.F., 2006. Atmospheric Nutrient Deposition at the East China Coast and its Impact on Marine Primary Production. M.S. Thesis. Ocean University of China, Qingdao, China, pp. 93 pp.

Borum, J., Sand-Jensen, K., 1996. Is total primary production in shallow coastal marine waters stimulated by nitrogen loading? Oikos 406-410.

Bricker, S.B., Longstaff, B., Dennison, W., Jones, A., Boicourt, K., Wicks, C., Woerner, J., 2008. Effects of nutrient enrichment in the nation's estuaries: a decade of change. Harmful Algae 8 (1), 21-32.

Chen, C.T.A., 2009. Chemical and physical fronts in the Bohai, Yellow and East China seas. J. Mar. Syst. 78, 394-410.
Cho, H.M., Kim, G., Kwon, E.Y., Moosdorf, N., Garcia-Orellana, J., Santos, I.R., 2018. Radium tracing nutrient inputs through submarine groundwater discharge in the global ocean. Sci. Rep. 8 (1), 2439.

Chung, C.S., Hong, G.H., Lim, S.H., Lim, J.H., Park, J.K., Yang, D.B., 1998. Shore based observation on wet deposition of inorganic nutrients in the Korean Yellow Sea coast. Yellow Sea 4, 30-39.

Conley, D.J., Humborg, C., Smedberg, E., Rahm, L., Papush, L., Danielsson, Å., Mörth, C.M., 2008. Past, present and future state of the biogeochemical Si cycle in the Baltic Sea. J. Mar. Syst. 73 (3-4), 338-346.

Cowan, J.L., Boynton, W.R., 1996. Sediment-water oxygen and nutrient exchanges along the longitudinal axis of Chesapeake Bay: seasonal patterns, controlling factors and ecological significance. Estuaries 19 (3), 562-580.

Cui, Y., Chen, B.J., Chen, J.F., 2005. Evaluation on self-pollution of marine culture in the Yellow Sea and Bohai Sea. Chin. J. Appl. Ecol. 16, 180-185.

Cui, Y.P., Wang, B.D., Chen, Q.W., 2013. Distribution of dissolved silicate and changes of Si:N and Si:P ratio in Yangtze River estuary before and after impoundment of Three Gorges Reservoir. Acta Sci. Circumst. 33 (7), 1974-1979.

DePinto, J.V., Verhoff, F.H., 1977. Nutrient regeneration from aerobic decomposition of green algae. Environ. Sci. Technol. 11 (4), 371-377.

Devlin, M., Bricker, S., Painting, S., 2011. Comparison of five methods for assessing im pacts of nutrient enrichment using estuarine case studies. Biogeochemistry 106 (2), 177-205.

Diaz, R.J., Rosenberg, R., 2008. Spreading dead zones and consequences for marine ecosystems. Science 321 (5891), 926-929.

Dortch, Q., Whitledge, T.E., 1992. Does nitrogen or silicon limit phytoplankton production in the Mississipi River plume and nearby regions? Cont. Shelf Res. 12, 1293-1309.

Duan, L.Q., Song, J.M., Yuan, H.M., Li, X.G., Li, N., 2016. Distribution, partitioning and sources of dissolved and particulate nitrogen and phosphorus in the north Yellow Sea. Estuar. Coast Shelf Sci. 181, 182-195.

Fan, X., Xu, D., Wang, Y.T., Zhang, X.W., Cao, S.N., Mou, S.L., Ye, N.H., 2014. The effect of nutrient concentrations, nutrient ratios and temperature on photosynthesis and nutrient uptake by Ulva prolifera: implications for the explosion in green tides. J. Appl. Phycol. 26, 537-544.

Gao, T.C., 2019. Exchange fluxes of nutrients across sediment-water interface in the Muping marine ranch and its adjacent waters. M.S. Thesis In: University of Chinese Academy of Sciences, Beijing, China, pp. 97 pp.

Giovanardi, F., Vollenweider, R.A., 2004. Trophic conditions of marine coastal waters: experience in applying the Trophic Index TRIX to two areas of the Adriatic and Tyrrhenian seas. J. Limnol. 63 (2), 199-218.

Glibert, P.M., Allen, J.I., Bouwman, A.F., Brown, C.W., Flynn, K.J., Lewitus, A.J., Madden, C.J., 2010. Modeling of HABs and eutrophication: status, advances, challenges. J. Mar. Syst. 83 (3-4), 262-275.

Gordon, D.C., Boudreau, P.R., Mann, K.H., Ong, J.E., Silvert, W.L., Smith, S.V., Wattayakorn, G., Wulff, F., Yanagi, T., 1996. LOICZ Biogeochemical Modelling Guidelines. LOICZ Reports and Studies (5). Texel, The Netherlands, pp. 96 LOICZ.

Grosse, J., van Breugel, P., Brussaard, C.P., Boschker, H.T., 2017. A biosynthesis view on nutrient stress in coastal phytoplankton. Limnol. Oceanogr. 62 (2), 490-506.

Guo, W.D., Zhang, X.M., Yang, Y.P., Hu, M.H., 1998. Potential eutrophieation assessment for Chinese coastal waters. J. Oceanogr. Taiwan Strait 17 (1), 64-70.

Han, L.J., Zhu, Y.M., Liu, S.M., Zhang, J., Li, R.H., 2013. Nutrient characteristics and source apportionment in atmospheric deposition of the Yellow Sea and East China Sea. China Environ. Sci. 33 (7), 1174-1184.

Han, Q.Y., Liu, D.Y., 2014. Temporal and spatial variations in the distribution of macroalgal communities along the Yantai Coast, China. Chin. J. Oceanol. Limnol. 32 (3), 595-607.

Hao, Q., 2010. The Distribution of Chlorophyll $a$ and Primary Productivity and the Environmental Control Mechanism in the China Sea Ship-Measured and Satellite Study. PhD. Dissertation. Ocean University of China, Qingdao, China, pp. 149 pp.

Heisler, J., Glibert, P.M., Burkholder, J.M., Anderson, D.M., Cochlan, W., Dennison, W.C., Lewitus, A., 2008. Eutrophication and harmful algal blooms: a scientific consensus. Harmful Algae 8 (1), 3-13.

Herrera-Silveira, J.A., Morales-Ojeda, S.M., 2009. Evaluation of the health status of a coastal ecosystem in southeast Mexico: assessment of water quality, phytoplankton and submerged aquatic vegetation. Mar. Pollut. Bull. 59 (1-3), 72-86.

Hong, H.S., 2012. Regional Oceanography of China Seas: Chemical Oceanography. Ocean Press, Beijing, pp. 374.

Humborg, C., Conley, D.J., Rahm, L., Wulff, F., Cociasu, A., Ittekkot, V., 2000. Silicon retention in river basins: far-reaching effects on biogeochemistry and aquatic food webs in coastal marine environments. Ambio 29 (1), 45-51.

Jia, Y.R., Liu, X.J., Sun, Y.L., Sun, C.Q., 2007. Argumentation of sewage discharge mixing zone's area of Xin'an River Sewage Plant of Yantai. Mar. Sci. Bull. 26, 33-37.

Jones, D.L., Shannon, D., Murphy, D.V., Farrar, J., 2004. Role of dissolved organic nitrogen (DON) in soil N cycling in grassland soils. Soil Biol. Biochem. 36 (5), 749-756.

Justic, D., Rabalais, N.N., Turner, R.E., 1995. Stoichiometry nutrient balance and origin of coastal eutrophication. Mar. Pollut. Bull. 30, 41-46.

Lee, Y.W., Hwang, D.W., Kim, G., Lee, W.C., Oh, H.T., 2009. Nutrient inputs from submarine groundwater discharge (SGD) in Masan Bay, an embayment surrounded by heavily industrialized cities, Korea. Sci. Total Environ. 407 (9), 3181-3188.

Lehtinen, S., Tamminen, T., Ptacnik, R., Andersen, T., 2017. Phytoplankton species richness, evenness, and production in relation to nutrient availability and imbalance. Limnol. Oceanogr. 62 (4), 1393-1408.

Li, C.X., Yang, G.P., Wang, B.D., 2015. Biological production and spatial variation of dimethylated sulfur compounds and their relation with plankton in the North Yellow Sea. Cont. Shelf Res. 102, 19-32.

Li, R., Liu, S., Zhang, J., Jiang, Z., Fang, J., 2016. Sources and export of nutrients 
associated with integrated multi-trophic aquaculture in Sanggou Bay, China Aquacult. Environ. Interact. 8, 285-309.

Li, R.H., Liu, S.M., Li, Y.W., Zhang, G.L., Ren, J.L., Zhang, J., 2014. Nutrient dynamics in tropical rivers, lagoons, and coastal ecosystems of eastern Hainan Island, South China Sea. Biogeosciences 11 (2), 481-506.

Li, Y.W., Hu, Y.Y., Chen, S.M., 2013. Distribution and influence factors of nutrients in the North Yellow Sea in summer and autumn. China Environ. Sci. 33 (6), 1060-1067.

Li, Z.Y., Bai, J., Shi, J.H., Gao, H.W., 2003. Distributions of inorganic nutrients in the Bohai Sea of China. J. Ocean Univ. China 2 (1), 112-116.

Liu, S.M., Hong, G.H., Zhang, J., Ye, X.W., Jiang, X.L., 2009. Nutrient budgets for large Chinese estuaries. Biogeosciences 6 (10), 2245-2263.

Liu, S.M., Li, L.W., Zhang, G.L., Liu, Z., Yu, Z., Ren, J.L., 2012. Impacts of human activities on nutrient transports in the Huanghe (Yellow River) estuary. J. Hydrol. 430, 103-110.

Liu, S.M., Zhang, J., Chen, H.T., Zhang, G.S., 2005. Factors influencing nutrient dynamics in the eutrophic Jiaozhou Bay, North China. Prog. Oceanogr. 66 (1), 66-85.

Liu, S.M., Zhang, J., Chen, S.Z., Chen, H.T., Hong, G.H., Wei, H., Wu, Q.M., 2003. Inventory of nutrient compounds in the Yellow Sea. Cont. Shelf Res. 23, 1161-1174.

Liu, Y.F., 2015. Rapid modeling Eutrophication Techniquesusin Optical Parameters of CDOM in the Coastal Waters. M.S. Thesis. Ocean University of China, Qingdao, China, pp. 70 pp.

Lui, H.K., Chen, C.T.A., 2011. Shifts in limiting nutrients in an estuary caused by mixing and biological activity. Limnol. Oceanogr. 56 (3), 989-998.

Lui, H.K., Chen, C.T.A., 2012. The nonlinear relationship between nutrient ratios and salinity in estuarine ecosystems: implications for management. Curr. Opin. Environ. Sust. 4 (2), 227-232.

Ma, Z.H., Wang, L., Wang, D.L., Yu, L., 2012. Evaluation and analysis on the quality of the sea water adjacent to the Yantai Xin'an River Estuary. Ludong U. J. 28 (4), 364-369.

Magni, P., Montani, S., Takada, C., Tsutsumi, H., 2000. Temporal scaling and relevance of bivalve nutrient excretion on a tidal flat of the Seto Inland Sea, Japan. Mar. Ecol. Prog. Ser. 198, 139-155.

Moncheva, S., Gotsis-Skretas, O., Pagou, K., Krastev, A., 2001. Phytoplankton blooms in Black Sea and Mediterranean coastal ecosystems subjected to anthropogenic eutrophication: similarities and differences. Estuar. Coast Shelf Sci. 53 (3), 281-295.

Nelson, D.M., Brzezinski, M.A., 1990. Kinetics of silicic acid uptake by natural diatom assemblages in two Gulf Stream warm-core rings. Mar. Ecol. Prog. Ser. 62, 283-292.

Newell, R.I., 2004. Ecosystem influences of natural and cultivated populations of suspension-feeding bivalve molluscs: a review. J. Shellfish Res. 23 (1), 51-62.

Niu, Y.L., 2014. Study on Seasonal Variation of the C, N, P, Si Budget of the Bivalves in Sanggou Bay. M.S. Thesis. Zhejiang Ocean University, pp. 79 pp.

Paerl, H.W., 1997. Coastal eutrophication and harmful algal blooms: importance of atmospheric deposition and groundwater as "new" nitrogen and other nutrient sources. Limnol. Oceanogr. 42, 1154-1165.

Pettine, M., Casentini, B., Fazi, S., Giovanardi, F., Pagnotta, R., 2007. A revisitation of TRIX for trophic status assessment in the light of the European Water Framework Directive: application to Italian coastal waters. Mar. Pollut. Bull. 54 (9), 1413-1426.

Pietros, J.M., Rice, M.A., 2003. The impacts of aquacultured oysters, Crassostrea virginica (Gmelin, 1791) on water column nitrogen and sedimentation: results of a mesocosm study. Aquaculture 220 (1-4), 407-422.

Primpas, I., Karydis, M., 2011. Scaling the trophic index (TRIX) in oligotrophic marine environments. Environ. Monit. Assess. 178 (1-4), 257-269.

Qin, G.H., 2018. Upgrade and renovation of Yantai Xin'anhe waste water treatment plant. China Water \& Wastewater 34 (12), 95-97.

Qu, H.J., Kroeze, C., 2010. Past and future trends in nutrients export by rivers to the coastal waters of China. Sci. Total Environ. 408, 2075-2086.

Qualls, R.G., Richardson, C.J., 2003. Factors controlling concentration, export, and decomposition of dissolved organic nutrients in the Everglades of Florida. Biogeochemistry 62 (2), 197-229.

Rabotyagov, S., Campbell, T., Jha, M., Gassman, P.W., Arnold, J., Kurkalova, L., Kling, C.L., 2010. Least-cost control of agricultural nutrient contributions to the Gulf of Mexico hypoxic zone. Ecol. Appl. 20 (6), 1542-1555.

Redfield, A.C., 1963. The Influence of Organisms on the Composition of Seawater. The Sea. Wiley Interscience, New York, pp. 26-77.

Richardson, K., 1997. Harmful or exceptional phytoplankton blooms in the marine ecosystem. Adv. Mar. Biol. 31, 301-385.

Rodellas, V., Garcia-Orellana, J., Masqué, P., Feldman, M., Weinstein, Y., 2015. Submarine groundwater discharge as a major source of nutrients to the Mediterranean Sea. P. Natl. Acad. Sci. USA 112 (13), 3926-3930.

Samuelsson, K., Berglund, J., Haecky, P., Andersson, A., 2002. Structural changes in an aquatic microbial food web caused by inorganic nutrient addition. Aquat. Microb. Ecol. 29 (1), 29-38.

Santos, I.R., Eyre, B.D., 2013. The contribution of groundwater discharge to nutrient exports from a coastal catchment: post-flood seepage increases estuarine N/P Ratios. Estuar. Coasts 36, 56-73.

Savchuk, O.P., 2005. Resolving the Baltic Sea into seven subbasins: N and P budgets for 1991-1999. J. Mar. Syst. 56 (1-2), 1-15.

Shahrban, M., Etemad-Shahidi, A., 2010. Classification of the Caspian Sea coastal waters based on trophic index and numerical analysis. Environ. Monit. Assess. 164 (1-4), 349-356.

Slomp, C.P., Van Cappellen, P., 2004. Nutrient inputs to the coastal ocean through submarine groundwater discharge: controls and potential impact. J. Hydrol. 295 (1-4),
64-86.

Smith, S.V., Hollibaugh, J.T., 1993. Coastal metabolism and the oceanic organic carbon balance. Rev. Geophys. 31, 75-89.

Song, J.M., 2009. Biogeochemical Processes of Biogenic Elements in China Marginal Seas. Springer-Verlag GmbH Zhejiang University Press, pp. 662.

Song, J.W., Zhang, C.S., Shi, X.Y., 2016. Distribution and influence factors of dissolved inorganic nutrients in the Southern Yellow Sea and Yangtze Estuary in summer and autumn. J. Ocean Univ. China 46 (9), 71-77.

Stevenson, F.J., Cheng, C.N., 1972. Organic geochemistry of the Argentine Basin sediments: carbon-nitrogen relationships and quaternary correlations. Geochem. Cosmochim. Acta 36 (6), 653-671.

Sun, X.Y., Su, R.G., 2016. A support vector machine-based technology for rapidly assessing trophic status of the Yellow Sea and the East China Sea. China Environ. Sci. 36 (1), 143-148.

Sun, P.X., Wang, B., Zhang, Z.H., Wang, Z.L., Xia, B., 2006. Relationship between nutrient distributions and eutrophication in seawater of the Laizhou Bay. Adv. Mar. Sci. 24 (3), 329-335.

Sun, W., Tang, X.C., Xu, Y.D., Zhang, H.J., Wei, X., Liu, Y.J., 2016. Characteristics of nutrients, restrictive analysis and eutrophication assessment in the Shuangdao Bay, Weihai. Sci. Technol. Eng. 16 (25), 168-172.

Tang, Y., Sun, Y.Y., Shi, X.Y., 2017. Distribution characteristics of chromophoric dissolved organic matter and nutrients from the Yellow Sea and Bohai Sea in autumn. Environ. Sci. 11, 57-68.

Troell, M., Joyce, A., Chopin, T., Neori, A., Buschmann, A.H., Fang, J.G., 2009. Ecological engineering in aquaculture-potential for integrated multi-trophic aquaculture (IMTA) in marine offshore systems. Aquaculture 297 (1-4), 1-9.

Vaquer-Sunyer, R., Duarte, C.M., 2008. Thresholds of hypoxia for marine biodiversity. P. Natl. Acad. Sci. USA 105 (40), 15452-15457.

Vollenweider, R.A., Giovanardi, F., Montanari, G., Rinaldi, A., 1998. Characterization of the trophic conditions of marine coastal waters with special reference to the NW Adriatic Sea: proposal for a trophic scale, turbidity and generalized water quality index. Environmetrics 9 (3), 329-357.

Wang, F.S., Wang, B.L., Liu, C.Q., Liu, X.L., Gao, Y., Zhang, J., Li, S., 2014. Changes in nutrient ratios and phytoplankton community structure caused by hydropower development in the Maotiao River, China. Environ. Geochem. Health 36, 595-603.

Wang, L.S., Zhang, C.S., Wang, H., Shi, X.Y., 2015. Long-term variations in biogenic elements of the Bohai Sea and the North Yellow Sea. Mar. Environ. Sci. 34 (3), 361-366.

Xing, H.Y., Sun, S., Ma, Y.Q., Bai, Y.Y., Jin, Y., Liu, Y.H., Qin, H.W., Li, B., 2013. Annual variation of nutrients and influential factors on it in Sishili Bay. Mar. Sci. Bull. 32 (1), 53-57.

Yang, B., Gao, X., 2019. Chromophoric dissolved organic matter in summer in a coastal mariculture region of northern Shandong Peninsula, North Yellow Sea. Cont. Shelf Res. 176, 19-35.

Yang, B., Gao, X., Xing, Q., 2018. Geochemistry of organic carbon in surface sediments of a summer hypoxic region in the coastal waters of northern Shandong Peninsula. Cont. Shelf Res. 171, 113-125.

Yang, J., Zhang, G.L., Zheng, L.X., Zhang, F., Zhao, J., 2010. Seasonal variation of fluxes and distributions of dissolved methane in the North Yellow Sea. Cont. Shelf Res. 30, 187-192.

Ye, L.A., Wang, L.B., Jiang, Z.F., Lu, S., Zhu, Z.Q., Li, D.L., 2017. Seasonal variations of distribution characteristics of nutrients in the East China Sea in 2015. J. Shanghai Ocean U. 3, 433-438.

Yu, Z.Y., 2014. Characteristics of Nutrient in the Southern Yellow Sea and Northern East China Sea from 2011 to 2013. M.S. Thesis. Ocean University of China, Qingdao, China, pp. 77 pp.

Yunev, O.A., Carstensen, J., Moncheva, S., Khaliulin, A., Ærtebjerg, G., Nixon, S., 2007. Nutrient and phytoplankton trends on the western Black Sea shelf in response to cultural eutrophication and climate changes. Estuar. Coast Shelf Sci. 74 (1-2), 63-76.

Zhang, G., Zhang, J., Liu, S., 2007. Characterization of nutrients in the atmospheric wet and dry deposition observed at the two monitoring sites over Yellow Sea and East China Sea. J. Atmos. Chem. 57 (1), 41-57.

Zhang, G.S., 2004. Atmospheric Dry and Wet Deposition and Impact on the Marine Ecosystem of Yellow Sea and East China Sea. M.S. Thesis. Ocean University of China, Qingdao, China, pp. 82 pp.

Zhang, J., 1994. Atmospheric wet deposition of nutrient elements: correlation with harmful biological blooms in Northwest Pacific coastal zones. Ambio 23, 464-468.

Zhang, Y., Gao, X., Guo, W., Zhao, J., Li, Y., 2018. Origin and dynamics of dissolved organic matter in a mariculture area suffering from summertime hypoxia and acidification. Front. Mar. Sci. 5, 325.

Zhao, C., Zang, J., Liu, J., Sun, T., Ran, X., 2016. Distribution and budget of nitrogen and phosphorus and their influence on the ecosystem in the Bohai Sea and Yellow Sea. China Environ. Sci. 36, 2115-2127.

Zhou, Y., Yang, H.S., He, Y.C., Zhang, F.Z., 2002. Nitrogen and phosphorus excretion and its ecological effect by several bivalves and fouling animals. Oceanol. Limnol. Sinica 33 (4), 424-431.

Zhou, Y.L., Zhang, C.S., Shi, X.Y., Su, G.R., 2017. Distribution characteristics of chlorophyll a and its influencing environmental factors in Bohai Sea and Yellow Sea. China Environ. Sci. 37 (11), 4259-4265.

Zhu, Y.M., 2011. Nutrients in Atmospheric Deposition of the Yellow and East China Seas. M.S. Thesis. Ocean University of China, Qingdao, China, pp. 89 pp. 